\title{
Revista Pulgarcito (1904-1907): la formación de un público infantil para la Argentina ${ }^{1}$
}

Pulgarcito Magazine (1904-1907): The formation of a children's audience in Argentina

\author{
María López García \\ CONICET / Universidad de Buenos Aires, Argentina \\ maguilopezgarcia@yahoo.com.ar
}

\section{RESUMEN:}

El artículo, enmarcado en el campo de la glotopolítica, estudia, sobre un corpus de 16 números, la revista infantil argentina Pulgarcito. En una primera instancia, el trabajo describe el contexto social y material de aparición de esa publicación. Luego, repasa las propiedades de las nuevas formas de circulación de la palabra escrita propiciadas por la modernización de las revistas, y las nuevas formas de lectura. Se propone demostrar que la explotación del segmento infantil comenzaría entonces una carrera, actualmente en vigor, en la formación del niño como consumidor, y que la prensa infantil argentina de fines del XIX y comienzos del XX jugaría un rol central en la difusión de ese modelo de infancia. Finalmente, analiza la gestión de contenidos vinculados con la modelación del ciudadano, la propuesta de nuevas formas de lectura extraescolares, y la presencia de distintas pautas lingüísticas como ensayos de lo que pronto se constituiría como forma lingüística de la prensa infantil en Argentina.

Palabras ClaVE: Prensa infantil argentina XIX, Español en la prensa siglo XIX, Prensa y escuela argentina siglo XIX.

\section{ABSTRACT:}

The article, framed in the field of glotopolitics, studiesthe Argentinean children's magazine Pulgarcito. In a first instance, the paper describes social and material context of Pulgarcito'sappearance. Then, it reviews the properties of written-word circulation (stimulated by the modernization of means oftransportation and written-press) and new ways of reading. Itproves that the exploitation of the children's nichewould, within that period, begin a strategy, currently in force, to educate the childas a consumer. Moreover, it also wants to probe that the Argentine children's press of the late nineteenth and early twentieth centuries would play a central role in the dissemination of that childhood model. Finally, it analyzes the presence of subjectsthat educate the citizenship, the management of new forms of extra-scholar reading, and the presence of different linguistic norms.

KEYWORDS: XIX century argentine children's press XIX, Spanish in the press XIX century, Press and school in XIXth, Century Argentina.

\section{INTRODUCCIÓN}

\subsection{Condiciones materiales}

El semanario infantil Pulgarcito es la primera revista moderna argentina destinada especialmente a ese público. El primer número sale el 18 de agosto de 1904 y, si bien el último número es de abril de 1907, solo el primer año puede ser considerada una revista para niños porque, a falta del éxito esperado, a partir de 1905 se transformaría en una revista para mujeres y, más adelante, para toda la familia, emulando a la entonces exitosísima Caras y Caretas. Por esa razón detenemos nuestro análisis en los números correspondientes a esa primera etapa. ${ }^{2}$

Su director, el uruguayo Constancio Cecilio Vigil, comenzó en 1904 su vida como empresario y creador de revistas en Argentina (aunque había iniciado su carrera a los 15 años en Montevideo, con la fundación de la revista La Alborada, y continuado con la dirección de los periódicos La Prensa y El País). ${ }^{3}$ Su primera producción argentina fue Pulgarcito, que editó junto a Enrique Antuña, escritor uruguayo de textos escolares de moral (quien pronto desaparecería de los créditos de tapa). La confluencia de varias condiciones llevaron a que Vigil silenciara en la publicación los nombres propios en textos e ilustraciones y a que en Pulgarcito no hubiera firma de autor para sus diferentes secciones. Por una parte, evitaba con ello filiar políticamente la 
revista (contrariamente a la práctica predominante en las publicaciones para adultos). Al mismo tiempo, la desanclaba de la órbita intelectual porteña y del canon de lecturas infantiles circulantes, y ahorraba los costos de contratación de colaboradores. En última instancia, ese silencio atendía a razones comerciales: la estrategia ético-publicitaria de Vigil consistió en ligar familia y empresa. ${ }^{4}$

La publicación constituyó un acontecimiento en virtud de su atención al nuevo segmento de la población que la poderosa iniciativa alfabetizadora estatal estaba creando y al que le asignaba un rol específico en la ciudadanía. Si bien se beneficiaba de y, a la vez, fortalecía el proyecto escolar, Pulgarcito intentó poner en marcha al lector infantil alternativo a la escuela.

Ese nuevo lector sería, en primera instancia, un lector de imágenes. Eso fue posible materialmente por las modernas técnicas de impresión recientemente arribadas al país, que introdujeron las imágenes a color y permitieron combinar en la misma página texto e ilustración, lo que a su vez posibilitó la composición del sentido en el diálogo de ambos códigos. ${ }^{5}$ La imagen aligeró la lectura e interpeló a nuevos sectores sociales y etarios no alfabetizados. Fragmentó la página, acelerando y dinamizando el recorrido, preparando al lector para la mirada fugaz. El tamaño y la calidad rústica del papel la abarataron y la hicieron manipulable. ${ }^{6}$ Estas condiciones del soporte le permitieron servir de complemento para la educación de un nuevo lector.

En las tapas que siguen puede verse la distancia entre la propuesta estética y material de Pulgarcito y las revistas infantiles que la precedieron, así como el vínculo directo con su contemporánea Caras y Caretas.

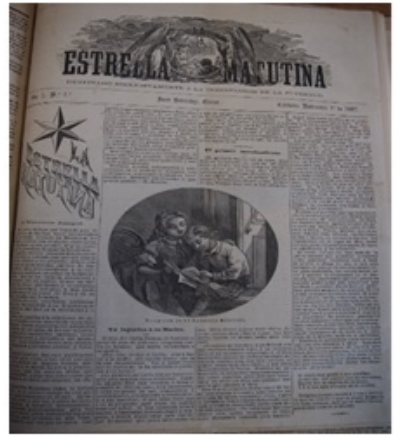

La estrella matutina (1867-1868)

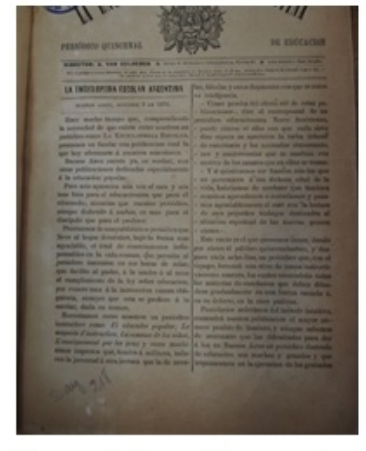

La enciclopedia escolar argentina (1875-1881)

Caras y Caretas (febrero de 1904)

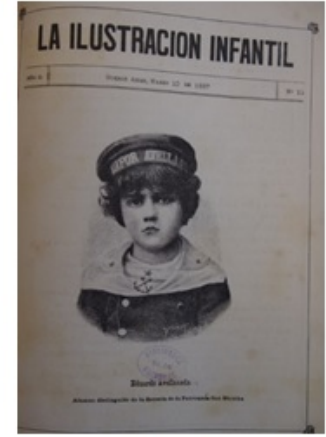

La ilustración infantil (1886-1887)

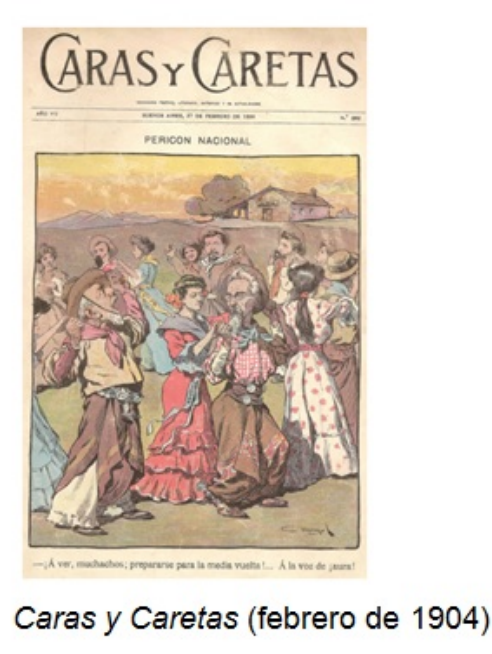

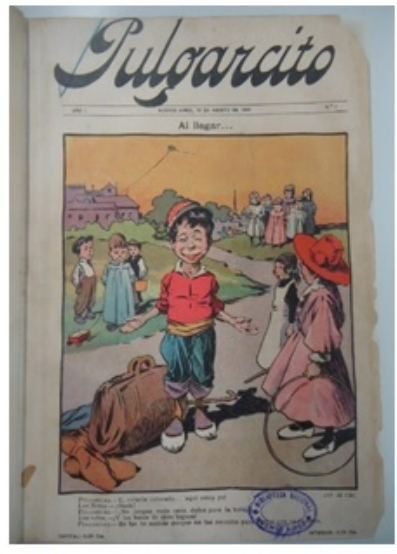

Pulgarcito (agosto de 1904)
Ese nuevo lector sería, además, consumidor, destinatario de publicidades (Pulgarcito constaba de 34 páginas de las cuales alrededor de 10 eran publicidad, lo que representó una novedad respecto de las revistas 
infantiles anteriores, que tenían unos pocos anuncios de la misma imprenta o acaso ninguno), y sería un lector demandante de entretenimiento.

El interés de Pulgarcito en posicionarse del lado de la prensa escrita y al margen de los libros escolares (controlados férreamente por el Estado a través de las Comisiones creadas a tal fin) se reflejó claramente en la circulación. El tendido ferroviario ${ }^{7}$ estaba transformando para siempre la distribución de impresos. La modernización del transporte permitió combinar la venta a través de agencias con los viejos medios de suscripción, aumentando las expectativas del negocio. La publicidad, entonces, comenzó a pesar como fuente de financiamiento y permitió mayor independencia respecto de la compra inmediata. En efecto, una característica definitoria de Pulgarcito radica en su financiación: mientras las revistas anteriores buscaban, por medio de la filiación con las prácticas escolares, integrar el poderoso aparato de comunicación del Estado, ${ }^{8}$ Pulgarcito confiaba en las suscripciones y en el despliegue de estrategias publicitarias específicas para ese público que la escuela hacía brotar a lo largo del territorio, nicho que Vigil pretendió capitalizar. ${ }^{9}$ Sobre un sistema prolífico de concursos ${ }^{10}$ buscó incentivar la suscripción, que se sumaba al ejercicio de los revendedores que en las provincias hacían extensiva la distribución a través de canillitas. La tapa atractiva y una cuidada relación entre precio, cantidad y calidad del material contribuyeron en el mismo sentido. Mordchunowitz (2010) afirma que llegó a estar en $5^{\circ}$ lugar en el índice de ventas de las publicaciones porteñas y tenía llegada a todo el país.

La distribución por suscripción, que recortaba el universo de lectores a las clases acomodadas, fue cayendo paulatinamente frente al creciente acceso del público popular a través de la venta en kioscos (cfr. Demarco 2009), reflejo de un incipiente cambio del universo lector de prensa periódica. La emergencia de un segmento infantil demandante de lecturas surgidas diferencialmente del ámbito de la prensa y no de la escuela obligó al despliegue de nuevas formas de leer y gestión de las características del consumo infantil.

La contratapa del segundo número concentra el modo de distribución y el universo de publicaciones en el que pretendió insertarse: incluyó un troquel para armar un kiosco de diarios. ${ }^{11}$

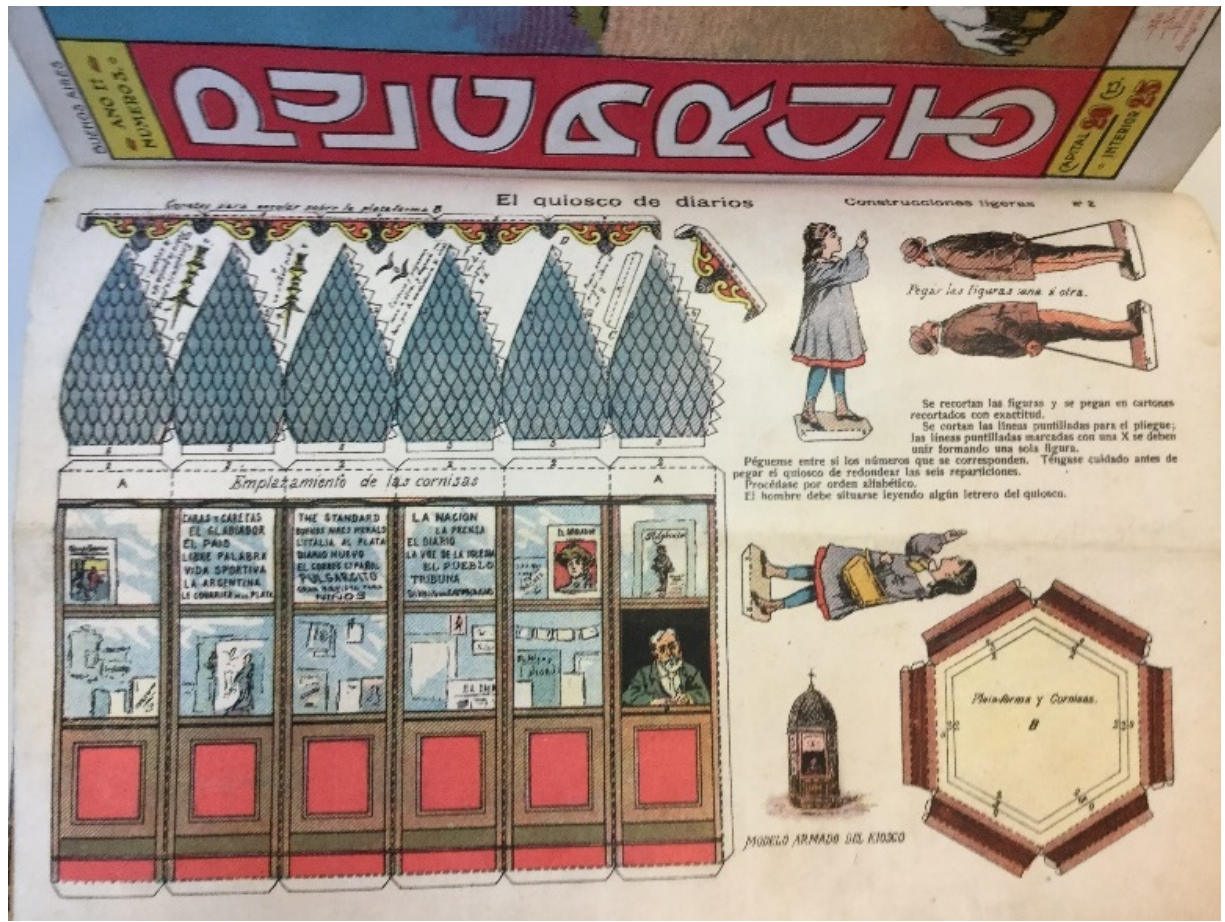

En ese kiosco con forma de garita hexagonal vidriada se publicitan los títulos de las publicaciones de los distintos colectivos y la prensa de mayor tirada: "Caras y caretas", "El gladiador" (cuya tapa figuraba aparte en otra ventanilla del hexágono), El país, Libre Palabra, Vida sportiva, La Argentina, Le courrier de la plata, The standard, Buenos Aires Herald, L'Italia al Plata, Diario Nuevo, El correo español, Pulgarcito [en letra mayúscula de tamaño significativamente mayor] gran revista para niños, La Nación, La Prensa, El Diario, La voz de la Iglesia, El Pueblo, Tribuna, Diario del comercio. 
Eso implicó depender de la pauta de anunciantes, lo que ahondaba el problema que representaban los niños, ese nuevo e incierto público, y los bienes y servicios de consumo que les estarían destinados.

\subsection{Condiciones legales: ¿quiénes eran los niños del 1900?}

La intervención estatal sobre la educación y, con ello, la regulación y definición del espacio de la infancia, se consagró en la Argentina en el año 1884 con la Ley de Educación Común No 1.420, principal acontecimiento en una serie de arduos debates que buscaron tamizar la infancia con un tramado legal. El Estado, al controlar el alcance de la escuela, de sus deberes y obligaciones -en tensión con los deberes y obligaciones de los padres-delimitó también el concepto de niño y de patria potestad:

La Ley de Patronato, al igual que la Ley de Educación Común, descansó sobre el principio de la preeminencia de las prerrogativas estatales sobre las de los padres toda vez que estuvieran en juego intereses colectivos tan preciosos como la conversión de los niños y jóvenes en ciudadanos honrados y trabajadores. Pero esto no implicaba que la atención de los niños y jóvenes extrañados de un marco familiar o vinculados en forma lábil con la autoridad adulta fuera concebida como un deber de las autoridades o como un derecho de los menores. Por el contrario, la complementariedad entre las instituciones estatales y la sociedad civil en el abordaje de las problemáticas vinculadas a la veloz urbanización de Buenos Aires constituía la regla y era pensada como positiva. (Zapiola, 2010: 11)

Como consigna profusamente en sus trabajos Carolina Zapiola (2010 y 2013), el período está teñido de debates legislativos acerca de las modalidades de intervención estatal sobre la infancia.

Según datos aportados por la investigadora, el segmento de 0 a 20 años representaba buena parte de la población de Buenos Aires: "en 1904, el 44.90\% de 950.891, en 1909, el 38.77\% de 1.231.698, y en 1914, el $41.05 \%$ de 1.575 .814 personas que vivían en la ciudad” (Zapiola 2009), de ahí se explica que pudiera preverse el éxito de una revista destinada a ese nutrido grupo. Pero otros números ponen en evidencia la todavía ineficaz propuesta del sistema educativo a los fines de orientar a las masas hacia el orden ciudadano deseado: de acuerdo con el mismo censo que refiere Zapiola, menos de la mitad de esos jóvenes estaba de algún modo escolarizado. De manera que casi una cuarta parte de la población de la ciudad eran niños o jóvenes que circulaban por los espacios urbanos - a causa de las ordenanzas que les prohibían la permanencia en los conventillos- o que desempeñaban tareas como venta ambulante, distribución y venta de prensa escrita, y mensajería. Además, los padres de aquellos niños que vendían o repartían periódicos eran en muchos casos inmigrantes, algunos de ellos promotores de ideas socialistas o anarquistas, lo que los criminalizaba y los hacía sujetos de políticas de reclusión y enajenación de la patria potestad de sus hijos.

Durante el cambio de siglo el campo simbólico de la infancia asoció "niño" con "hijo" y "alumno", y "menor" con "huérfano", “deambulante”, "vago”, y "delincuente” (Rodríguez López, 2010): los "niños” tenían hogar, padres e iban a la escuela; los "menores" eran huérfanos de padre, madre o ambos, vivían en conventillos y circulaban por el espacio público sin control, e incluso trabajaban. En función de esta partición, el Estado debió buscar formas alternativas de controlar a los infantes que, o bien quedaban fuera del alcance de la escuela (institución que, por otra parte, aún no terminaba de cuajar prácticamente por falta de infraestructura, materiales, maestros y organización administrativa), o bien porque la abandonaban prontamente para inclinarse al mundo del trabajo (o, se temía, de la delincuencia): ${ }^{12}$

Los vagabundos de Buenos Aires [...] estos, hoy niños vagos, inútiles, perdidos, parásitos sociales; mas tarde hombres de la misma condición con caracter mas acentuado. (Editorial del $1^{\circ}$ de septiembre de 1883 de la revista para docentes "La Revista Pedagógica" [extensión del texto: 2 páginas y media, casi un tercio de la revista]) 
La escuela se ocupaba de los niños, mientras que, para los menores, el destino eran las, todavía en ciernes, instituciones de reclusión (hasta entonces se resolvían parcialmente los problemas de los huérfanos, abandonados y "delincuentes" con reformatorios o cárceles de adultos). Luego, en el encuadre higienista de medicalización de la población y propagación de la metáfora biológica sobre el cuerpo social, se pasó de un relato delincuencial a un relato psíquico: el de las enfermedades morales; para estas, el encierro no sería ya la cárcel, sino los reformatorios (cfr. Rodríguez López 2010 donde se repasa el impacto que las condiciones sociales y criminalísticas tenían sobre los niños en las calles y la legislación regulatoria del trabajo infantil).

En este contexto es destacable la opción de Pulgarcito por mostrar en su primera tapa niños afuera de la escuela en un escenario de juego al aire libre (cfr. supra la tapa del primer número). Las novedosas características antes mencionadas de la distribución a partir de kioscos de diarios a la que suscribía Pulgarcito impactaron también en la representación positiva del menor vendedor de diarios.

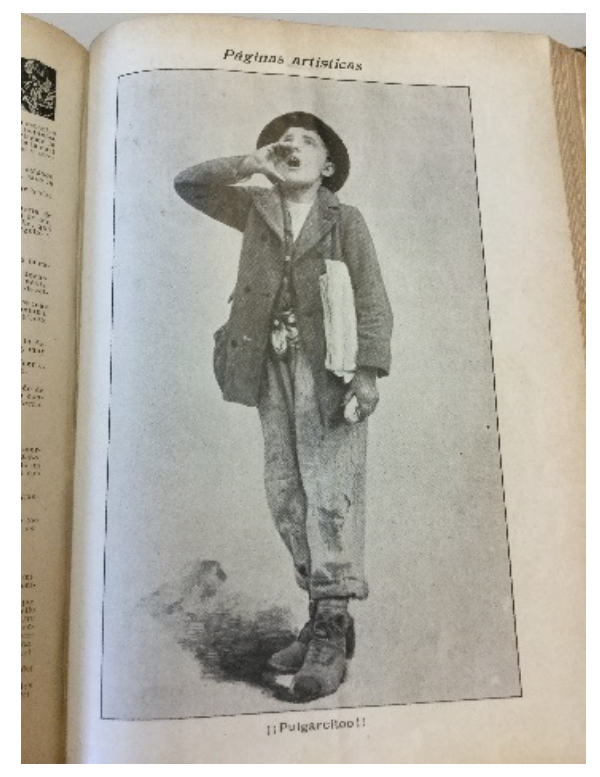

\subsection{Ritos de diferenciación de la infancia}

Ese posicionamiento refleja el cambio que la escuela y la prensa escrita estaban operando para la diferenciación de la infancia respecto del mundo adulto y su identificación positiva a partir de roles sociales, en especial los relacionados con las formas de vida urbana capitalista. Como veremos, Pulgarcito, al tiempo que refuerza la segmentación social por edad, género y clase, comienza a desdiferenciar "niños" de "menores", y fortalece su inmersión en la cultura letrada como rito de pasaje hacia el mundo adulto en la cultura moderna occidental (la sección "Niños del mundo" retrataba sus costumbres y formas de vida en rincones remotos del planeta). Desde Pulgarcito se construyen y delinean subjetividades infantiles en la asistencia a la escuela, en tipos de consumo y formas de circulación por la ciudad, reforzando el espacio deseado de la infancia, que implicaba saber leer y escribir, y mantenerse alejado tanto del mundo del trabajo como del vagabundeo por la ciudad. Esto suponía que los consumos y las prácticas antes usuales entre los menores (como fumar o beber alcohol) fueran ahora prohibición constitutiva. Miguel Cowen (2004) rescata un comentario iluminador de Benito Quinquela Martín:

Como él mismo lo refiere, un día su padre lo despertó de madrugada y le dijo: "vístete que tienes que venir conmigo", caminaron hasta el puerto donde había amarrados barcos cargados de carbón provenientes de Entre Ríos; fue su primer día de obrero portuario. Regresaron a la casa al mediodía, el viejo, sin decir nada, le sirvió un vaso de vino, y después de comer le convidó el primer cigarrillo. Esos gestos eran claros para Benito, eran el pasaporte al mundo de los adultos. (Cowen, 2004: 87) 
Las publicidades de tabaco constituyen el hito en la diferenciación de público e implicaban un posicionamiento en relación a la especial protección que debía recibir la infancia. Según Alejandro Butera, hasta los años 20 proliferaron los anuncios de tabaco que incluían niños (así como también mujeres semidesnudas y escenas amorosas, entre otras ilustraciones) como estrategia publicitaria, y era relativamente usual que los niños pequeños fumaran. Cita como ejemplo una publicidad de comienzos del siglo XX en Buenos Aires en la que un niño pequeño promociona "Mamita no se enojó, ni me dició renacuajo, poquetoy un home yo, y taménpo te me vió, que fumaba VUELTA ABAJO” (Butera, 2012: 75). La representación imperante era que fumar convertía a los niños más rápidamente en hombres.

En Pulgarcito no solo no se publicitaban cigarrillos, sino que se desaconsejaba su uso en menores. En tanto la revista tuvo claro su universo de recepción y el cambio de paradigma respecto de la infancia, se mantuvo en una línea publicitaria que vinculaba a los niños con la escuela, la higiene y el buen comportamiento (aunque más adelante, compelida por la necesidad de ampliar el público, fue incluyendo publicidades que incluso contradecían los relatos moralizantes e higienistas de los primeros números). A través de las imágenes instruyó en las nuevas conductas propias de la infancia: pasear, festejar cumpleaños, jugar al fútbol, hacer reuniones de costura, etc.
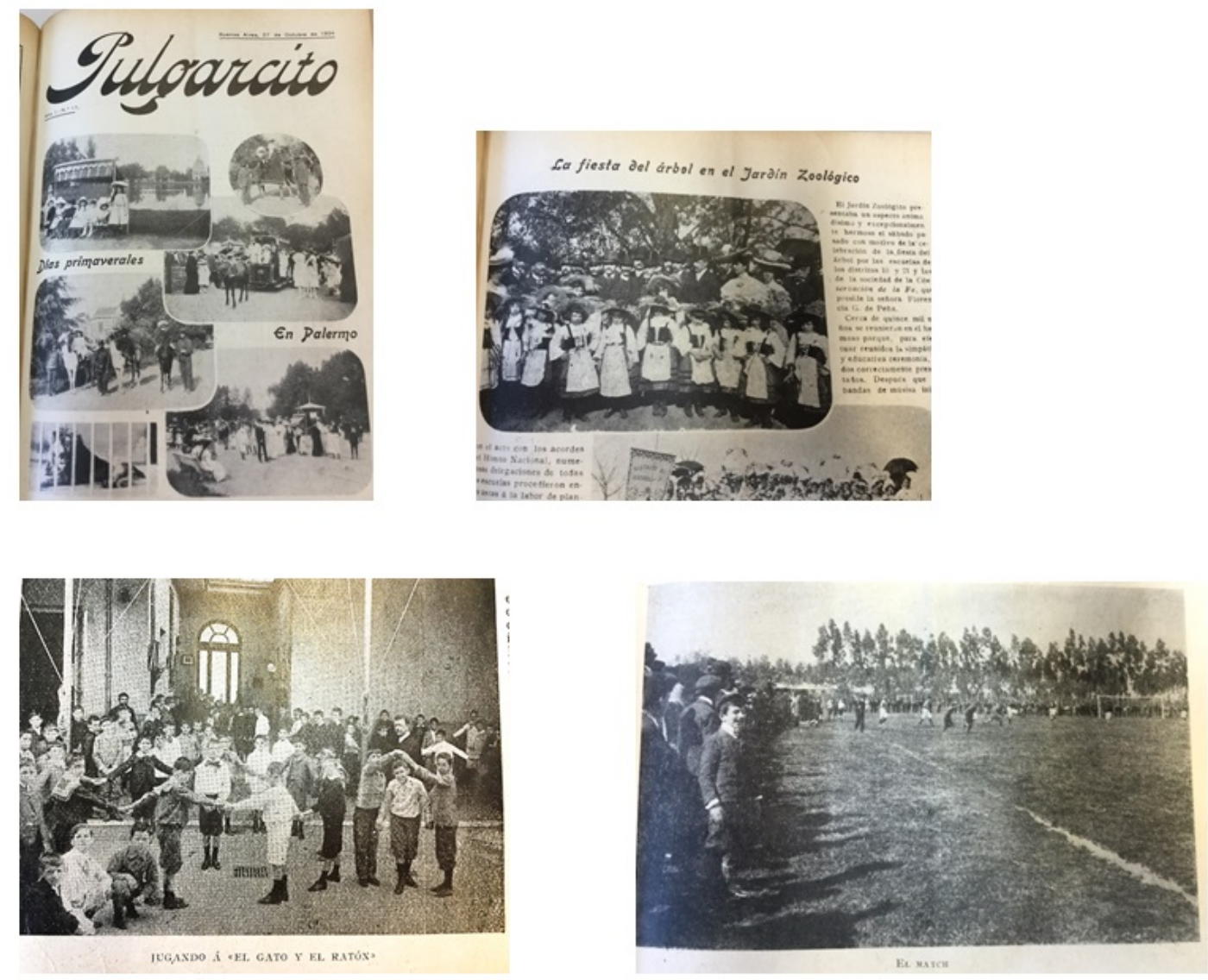

\section{Los Lectores/consumidores de Pulgarcito}

Como parte de una indudable estrategia de venta, y del proyecto identificador del segmento, el "protagonista" de la revista aparece fotografiado en varias de sus páginas. Si bien registramos un antecedente en la publicación argentina La ilustración infantil (1886), esa revista retrataba individuos (nunca conjuntos) que se destacaran en su inclinación a la tarea escolar. En Pulgarcito los niños aparecen agrupados 
(multiplicando los compradores del número, pero también) generando la conciencia de la niñez como nicho social, y son retratados independientemente de su conducta escolar. La presencia de los niños se atribuye, exclusivamente, a su relación con el semanario, allí los niños y los menores son el mismo conjunto de intereses: son los lectores de Pulgarcito. Con ello seguía el modelo de Caras y Caretas en el sentido de que el mero consumo de la revista constituía al público (Szir, 2009a) y no era necesario participar de circuitos culturales previos (aunque la revista suponía siempre a un niño inserto en una institución -escuela, hospicio, club-).

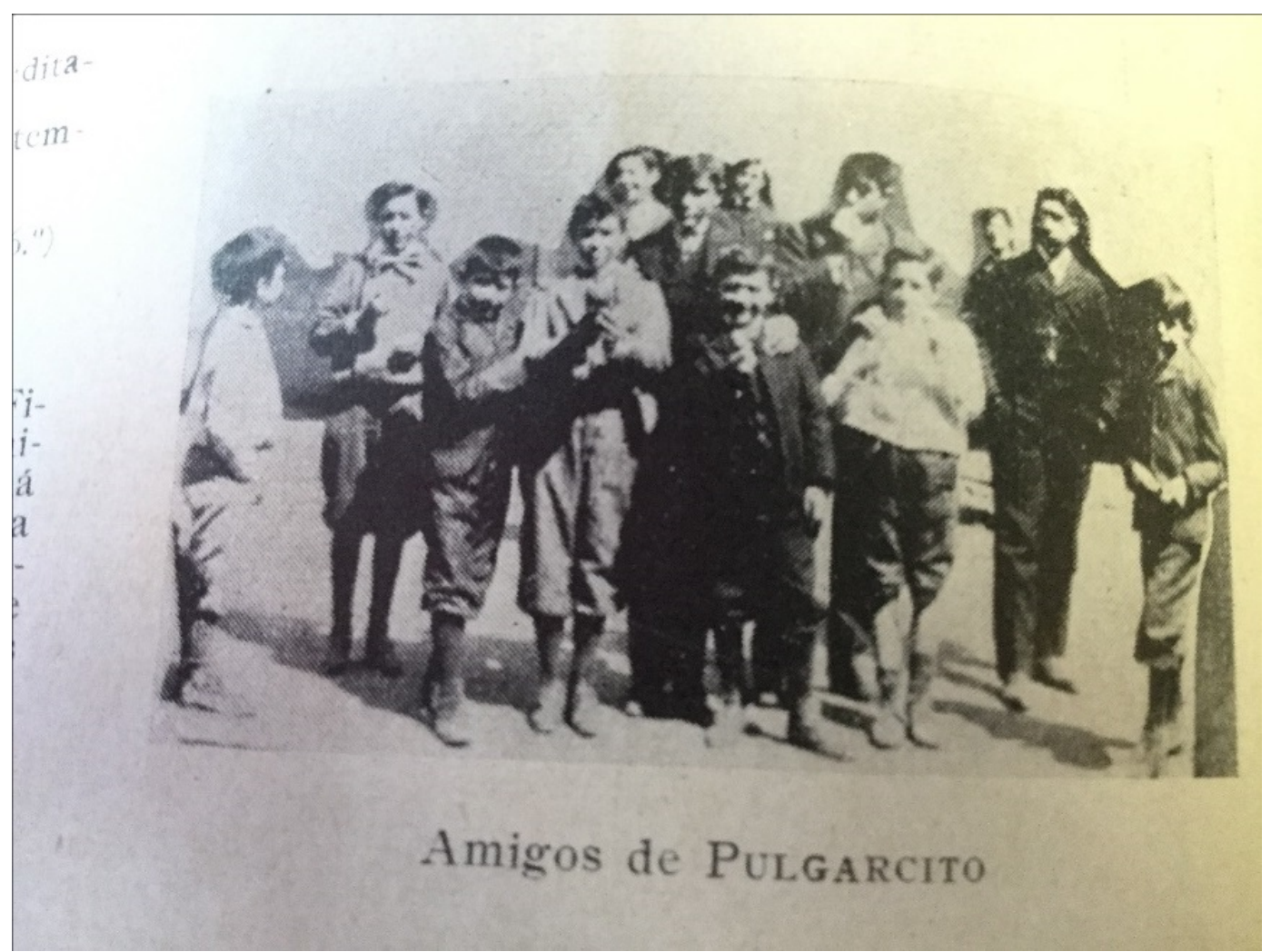

Es interesante destacar que el hecho de que aparecieran fotografías de los niños y contenidos enciclopédicos obligaba de algún modo a la conservación del material, aunque, al mismo tiempo, se incluían troqueles para recortar juguetes, moldes de vestidos, puntos de bordado, etc. La revista como soporte se encabalgaba así entre la lógica de la perduración, propia del libro (y de otras revistas infantiles anteriores, que estaban pensadas para ser encuadernadas en volúmenes, al estilo de las revistas ilustradas del resto mundo, cfr. Tell en Malosetti Costa, 2009: 156) y lo efímero del juego, del juguete de cartón.

Esto representó una novedad en la Argentina que los chicos resintieron: se les pedía pensar la letra escrita en la lógica de los consumos perecederos, aprovechar la alfabetización para la lógica del mercado: "Pero, como quiero hacer la colección, le ruego que no nos obligue á cortar las páginas de lectura para los concursos” (carta de lector $\mathrm{N}^{\circ} 11$ ).

Ese encabalgamiento confirma la búsqueda de nuevas formas de lectura (de chistes, acertijos, pequeños relatos con remate, viñetas), las lecturas efímeras, no destinadas a la memorización ni que luego fueran a ser controladas o valoradas (como sucedía en los antecedentes argentinos de la prensa infantil):

En primer lugar, leedme detenidamente y no á la lijera, como por pasa-tiempo; los cuentos no deben devorarse, sinó leerse. No os espongáis á que os respondan como á un amiguito mio que, interrogado sobre el asunto de un libro que terminaba de leer, respondió: «No podrán decirlo, porque en verdad devoro las novelas». «Se ve bien, que os han hecho indigestión» agregó el primero. Qué mortificación justa! Oh! no la merezcáis jamás. (“El escolar argentino”, 1894, No 6: 1) 
Pulgarcito supo capitalizar la alfabetización para la lógica del mercado, educó en el soporte descartable y en la lectura de divertimento. ${ }^{13}$ Buscó ocupar un lugar complementario de la educación escolar, pero gestionando el hábito de la lectura por placer, la lectura ociosa, la "lectura irrisoria, descartable" (como la llama Yole Zolezzi, discípula de Sarah Eccleston, desde la Revista de enseñanza que dirigía hacia 1895) que acompañaba y fortalecía esa sociedad alfabetizada generada por la escuela y que prosperaría sostenida por el enorme aparato de prensa que promovía la práctica constante de lectura.

\subsection{Orden y consumo}

La segmentación e instrucción del público consumidor es en Pulgarcito la misma operación. El niño convocado (y convalidado desde la currícula y la práctica escolar normalista) es el de una nación participante de la circulación global del capital, cuya orientación ideológica estaba diseñada para acompañar un modelo político económico productivo asociado a la industrialización como subsidiaria de las necesidades del agro (complementado por la confianza y admiración en los avances tecnológicos). Pulgarcito reafirma en distintas secciones la propuesta normalista resultante del congreso pedagógico de 1882.

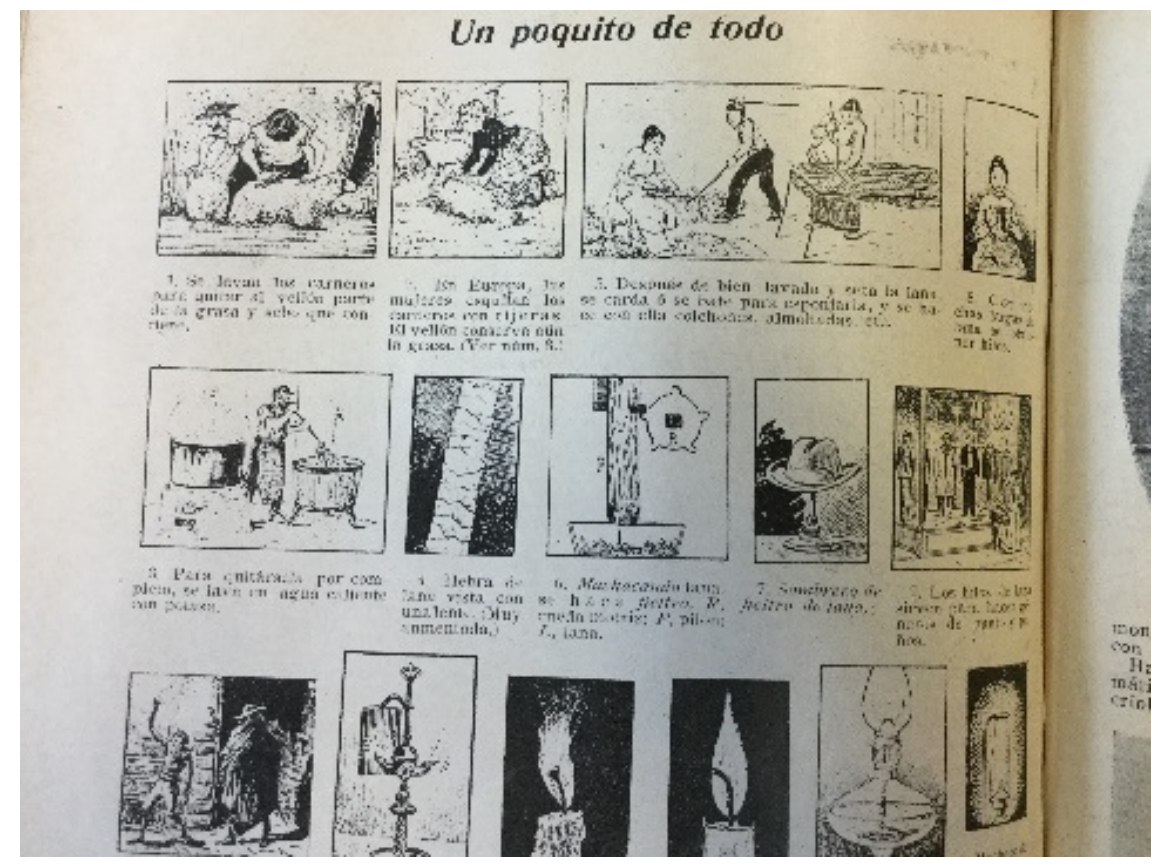

En la figura se reproduce la sección "Un poquito de todo", miscelánea sobre el aprovechamiento industrial de bienes naturales

El orden de lo científico aplicado a la ciudadanización redundó, entre otros fenómenos, en la patologización del cuerpo: campañas de vacunación, enseñanza del aseo personal, limpieza edilicia, ordenamiento urbano, etc.; y alcanzaba el orden doméstico, atravesando con la voz estatal del saneamiento la barrera del ámbito privado. El discurso científico (y las metáforas asociadas) pasaba a ser el modo en que el orden de lo público y lo privado organizaban su protección respecto del potencial peligro de aquellas sustancias que no se dejaban ver. En la misma perspectiva se explica la preeminencia de la vista como órgano validador, que se sintetiza en el objeto fetiche de las publicaciones infantiles de la época: el microscopio (al Pulgarcito le destinó una sección fija). 


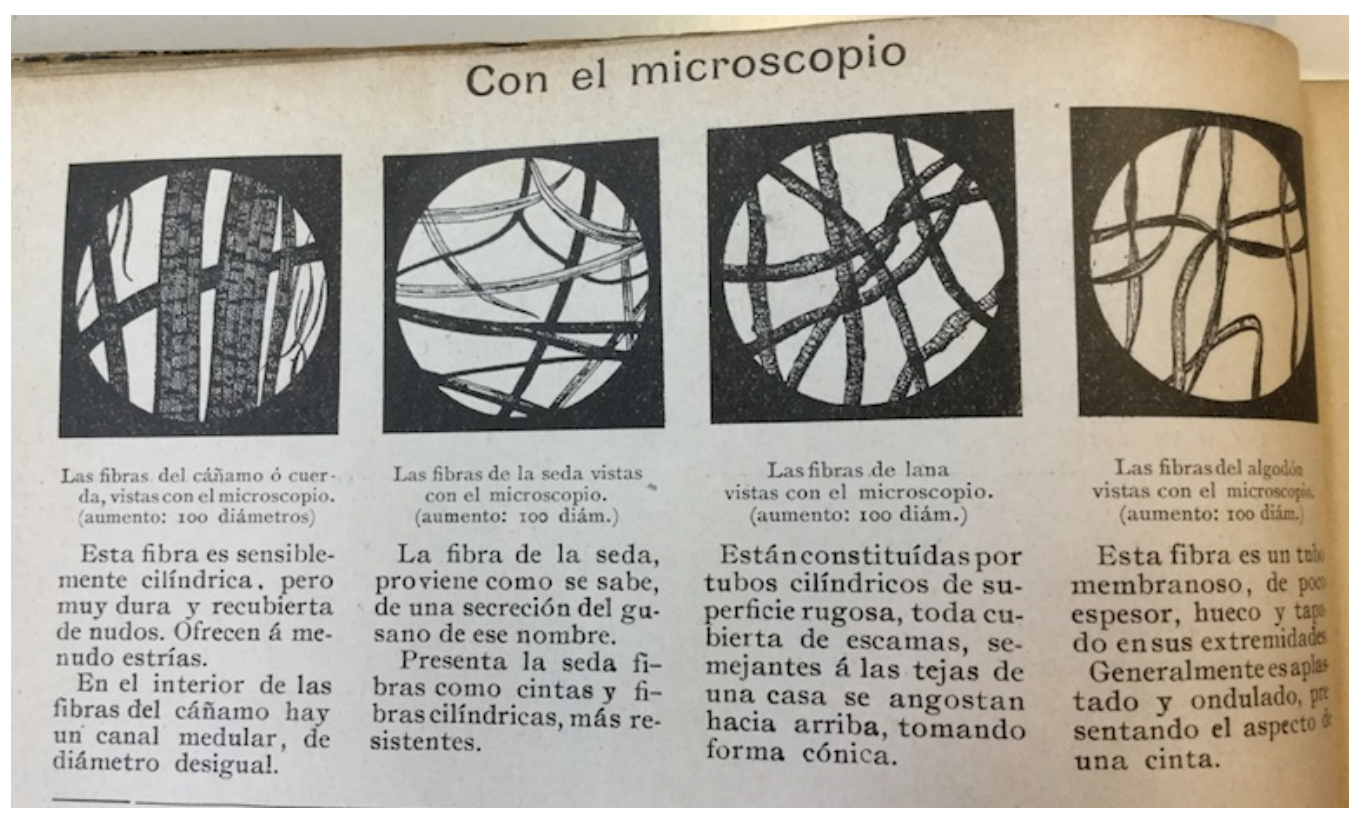

Por medio de este tipo de estrategias la prensa estableció vínculos entre la tecnificación de la mirada y la construcción de la verdad. La incipiencia del desarrollo técnico para la reproducción de la imagen implicó generar un aparato de interpretación de lo visible, que optó por la lógica de lo científico y el consecuente empleo de las técnicas de multiplicación y ampliación como efectos de verdad desde una cosmovisión tecnocrática. En ese sentido, el entrenamiento en la lectura de imágenes a través de la prensa era parte del programa de educación para la confianza en la reproducción técnica.

\subsection{Educación del tiempo libre y segmentación social}

La prensa se ocupó de entrenar la lectura de señales de codificación crecientemente compleja en función de las necesidades del capital. En consonancia con la lógica racional, era preciso construir un sujeto social segmentado. No solo la escuela o el vínculo con el Estado definía/identificaba al niño, sino también sus consumos. La revista gestionó un niño lector/consumidor de publicidad (medicamentos, comida procesada, productos de higiene, moda) y lectura de entretenimiento. Esto significó generar la representación de que ningún género estaba asociado a la lectura por "pura obediencia", y andamiar la lectura de bloques yuxtapuestos de información y de imágenes. La lectura ociosa ofrecida en la prensa infantil resultaba así funcional a la operación ordenadora de las instituciones instructoras de la cultura escrita. Habermas (1981) recuerda que el ocio supone la categoría rectora del trabajo ${ }^{14}$ (de ahí la idea del buen uso del tiempo libre o del dinero invertido allí, como señala Pulgarcito insistentemente).

Pocos años más tarde, el Ministerio de Educación argentino (a través del Monitor de la Educación Común, su órgano oficial de comunicación) corroboraría la función complementaria de estos disciplinamientos:

Es incuestionablemente de vital importancia que el pueblo de un estado democrático sea inteligente, puesto que le compete dar su dictamen por medio del voto. [...] Como el buen sentido en asuntos corrientes no prospera bien en la atmósfera nerviosa y llena de precipitación de nuestra civilización industrial, el espíritu ha de consagrarse por su cuenta a buscar equilibrio y horizonte por medio del estudio y de la disciplina conscientes, después de terminadas las faenas del día. [...] El espíritu de los trabajadores hállase hoy en estado de inquietud y necesita un elemento vital que lo tranquilice. [...] Si poseyera estas cosas [propósito en la vida y tranquilidad del ocio], su protesta contra las condiciones en las que vive sería menos acerba; tal vez podría promulgarlas de manera más eficaz; y no lo extraviarían con tanta frecuencia quimeras sociales y económicas. (Weaver Pangburn en “Monitor de la Educación Común”, 1924 Año 42 (88): 83-86) 15 
La lógica escolar, que implicaba la partición del tiempo en el espacio (regulando entrada y salida, recreo, los momentos destinados a las distintas asignaturas, etc.) y la sujeción de los cuerpos y sus modos de circulación en la vida pública se proyectó programáticamente sobre el ámbito privado y sobre las prácticas no escolares. Complementariamente, se educó la diversión (entendida como lo contrario del aburrimiento) como forma de participación urbana y doméstica. La diversión previno, además, el ocio negativo, no productivo (o reproductor) del estado de cosas (Dumazedier, 1968). En ese sentido, el mercado del ocio (revistas, pero también teatros, museos, salas de concierto, eventos deportivos, etc.) acompañó al Estado en la necesidad de educar para la organización del tiempo de la producción, de la circulación y de la permanencia. La propuesta de Pulgarcito rellenó ese espacio vacío del niño (futuro ciudadano, futura madre de familia) que ahora descubría la escuela, completando el moldeo de ese nuevo agente social diferenciado.

Pertenecer al público de Pulgarcito (y aparecer en sus páginas a través de una carta, una composición, una fotografía) era el premio de los concursos. El premio era pertenecer a un grupo nuevo de lectores, los lectores de las escuelas privadas de los barrios pudientes; de los clubes de Belgrano, San Isidro, Lomas de Zamora; de los que podían comprar Pulgarcito y leer afuera de la escuela. La lectura ociosa circula así como un bien de consumo marcador de estatus.

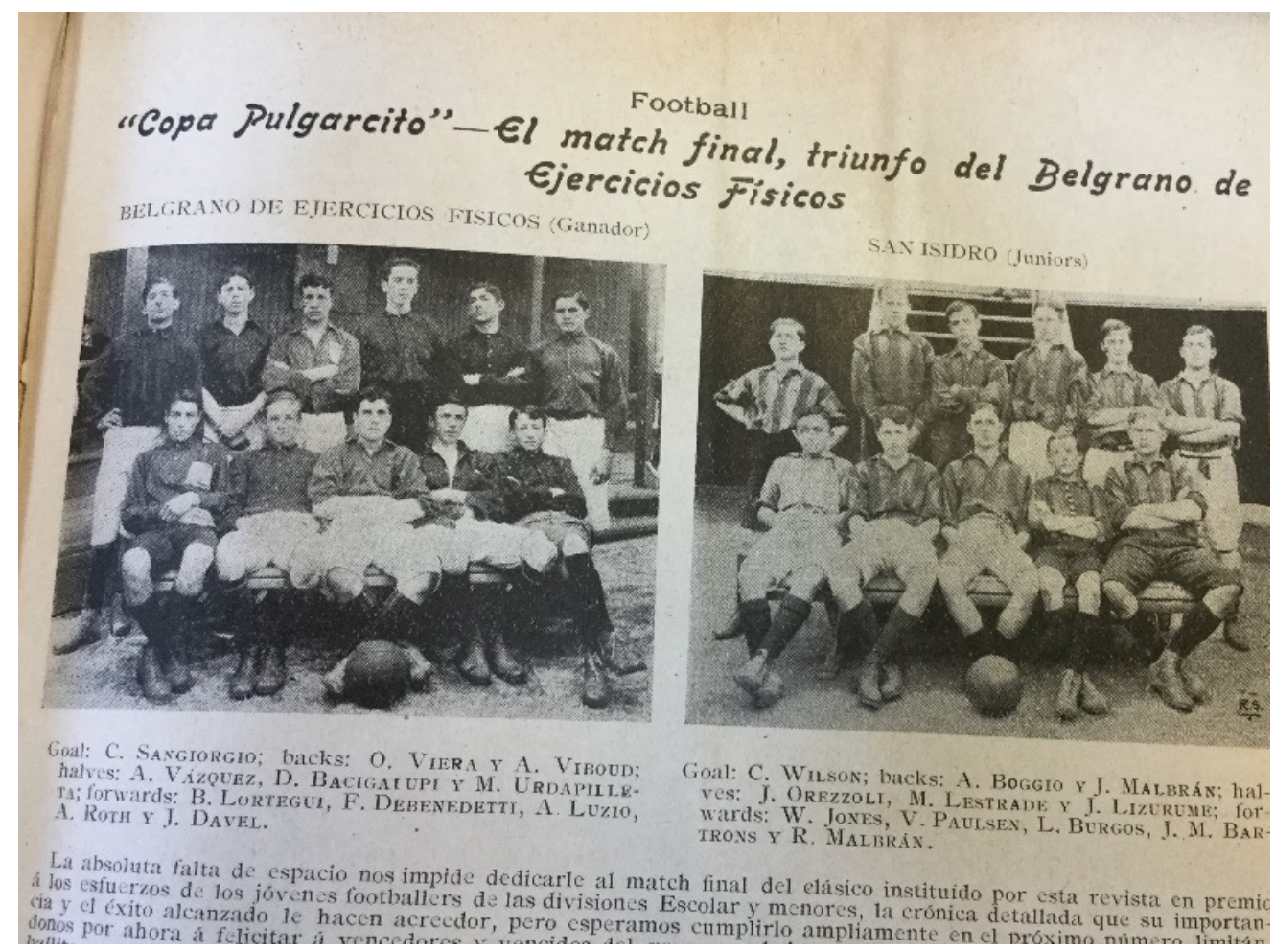

En la sección "el mañana” se espeja el público, fotografiado. Las escuelas representadas responden, reproduciendo la estructura de clases requerida por el sistema de producción, mayormente al perfil socioeconómico alto (colegios privados del barrio de residencia de altos ejecutivos ingleses: Southampton Belgrano, English High School, Prince George Hall, etc.), clase con poder de compra de la revista y objetos de identificación social para el resto. Aunque también son representados los otros niños (instituciones estatales de acogida, colegios de monjas, pupilajes). 


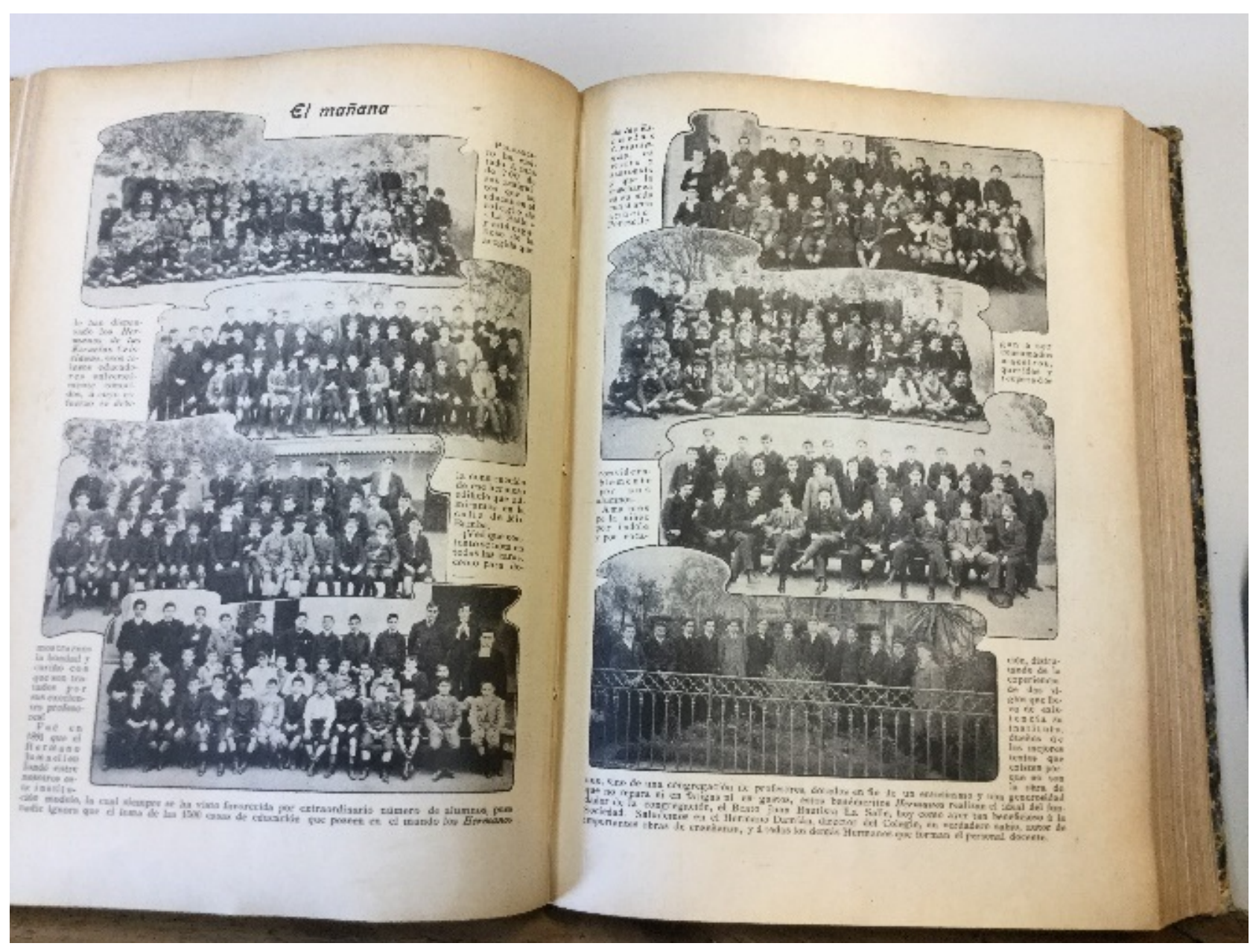

El deporte ocupó un espacio privilegiado ${ }^{16}$ (en especial, fútbol y esgrima) ${ }^{17}$ para modelar la conducta en contextos grupales, ${ }^{18}$ estimular el espíritu competitivo como pauta de participación social de los hombres y democratizar los estratos sociales reencauzando la tensión en campeonatos entre escuelas pudientes y hospicios (es decir, entre "niños” y “menores”). El deporte, señalan Elias y Dunnig (1992), es funcional para estimular el espíritu competitivo (modera y orienta la violencia), y educa un ocio "productivo" y dirigido a la sujeción del cuerpo y las costumbres. En Pulgarcito el ocio representado en el deporte era un coto exclusivamente masculino, ${ }^{19}$ mientras que, en la misma lógica de género y clase, la socialización femenina se instalaba en el ámbito privado y se concentraba en educar para la domesticidad y el desempeño en sociedad con miras al matrimonio y la maternidad (hay entonces fotos de eventos sociales, presentación de muñecas, rifas de beneficencia, moldes de vestidos...). ${ }^{20}$

En el otro extremo se ubicaban los "menores", los niños pobres, sin acceso a la salud y en manos del Estado. Aunque Pulgarcito les estaba destinado a todos por igual, cada niño era retratado en la sección que le correspondía. 

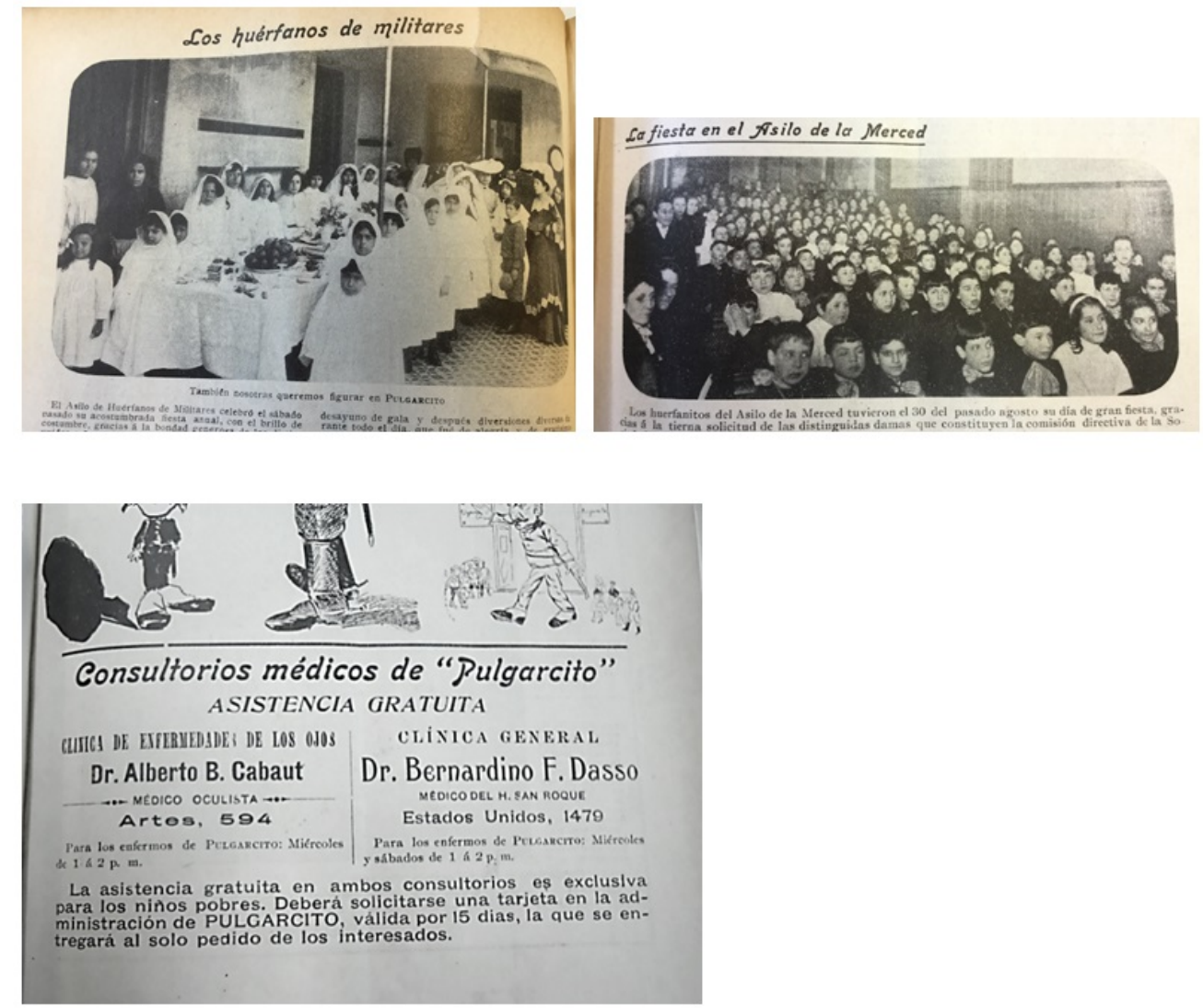

\section{LAS DIFICULTADES DE INTERPELAR A UN PÚBLICO QUE TODAVÍA NO EXISTE}

La impresión que PULGARCITO me ha causado es excelente. Los niños no teníamos ninguna revista para entretenernos y reirnos, porque los periódicos como Caras y Caretas, El Gladiador y otros de esa especie son muy buenos y útiles para personas mayores, pero los sucesos de que se ocupan principalmente son políticos ó sociales, cosas que nos son indiferentes porque no podemos apreciarlas. ( $\left.\mathrm{N}^{\circ} 1\right)$

Nuestro diario

¡Cuán difícil deciros, lo que más me ha gustado! He devorado todo, y todo es lindo, todo es bueno!... ¡Ay! Cuando sea hombre, no tendré más á PULGARCITO. ¡Dichoso él que siempre se queda chico!... ¿Por qué no deberíamos tener nosotros nuestro diario, que sólo se ocupara de nosotros? ¡Y éste ya llegó!... ¡Viva PULGARCITO! ( No $^{\circ}$ )

Si bien la revista estuvo en la calle semanalmente entre el 18 de agosto de 1904 y el 10 de abril de 1907 (llegó a salir hasta el No 139), solo hasta diciembre de 1904 ( $\mathrm{N}^{\circ}$ 16) puede ser considerada una revista puramente infantil. Las publicidades, los contenidos, las fotografías, los chistes de tapa y de margen inferior de página, la sección de moda, los entretenimientos, etc. estaban exclusivamente destinadas a ese público solo en sus primeros números. Sin embargo, representan un enorme salto cualitativo en relación a la construcción del público infantil respecto de las revistas anteriores, y es por eso que consideramos deben ser estudiadas especialmente. A tal punto los inicios de Pulgarcito fueron señeros en relación a la interpelación de esa nueva infancia que dieciséis años después Vigil lograría un éxito perdurable con la misma idea de Pulgarcito. Este segundo intento llevó por nombre Billiken y sigue vigente en la actualidad. 
Como mostraremos más adelante, Pulgarcito desplegó diversas estrategias para montarse sobre el discurso contenidista de la escuela normal y, al mismo tiempo, plantearse como lectura del ocio infantil. Este encabalgamiento hizo de la revista un híbrido que no dejó de perseverar en la búsqueda de un público que no lograba cuajar. Consecuentemente, cada número incluyó una sección con preguntas y pedidos de opinión sobre las secciones preferidas de la revista y sugerencias de nuevas secciones. Durante el año en que la revista fue exclusivamente infantil se realizaron 48 concursos ( 3 de ellos sobre composición) como recurso de fidelización y testeo de recepción (cuyos resultados eran publicados junto con los nombres de los ganadores, del colegio al que pertenecían y de su maestra).

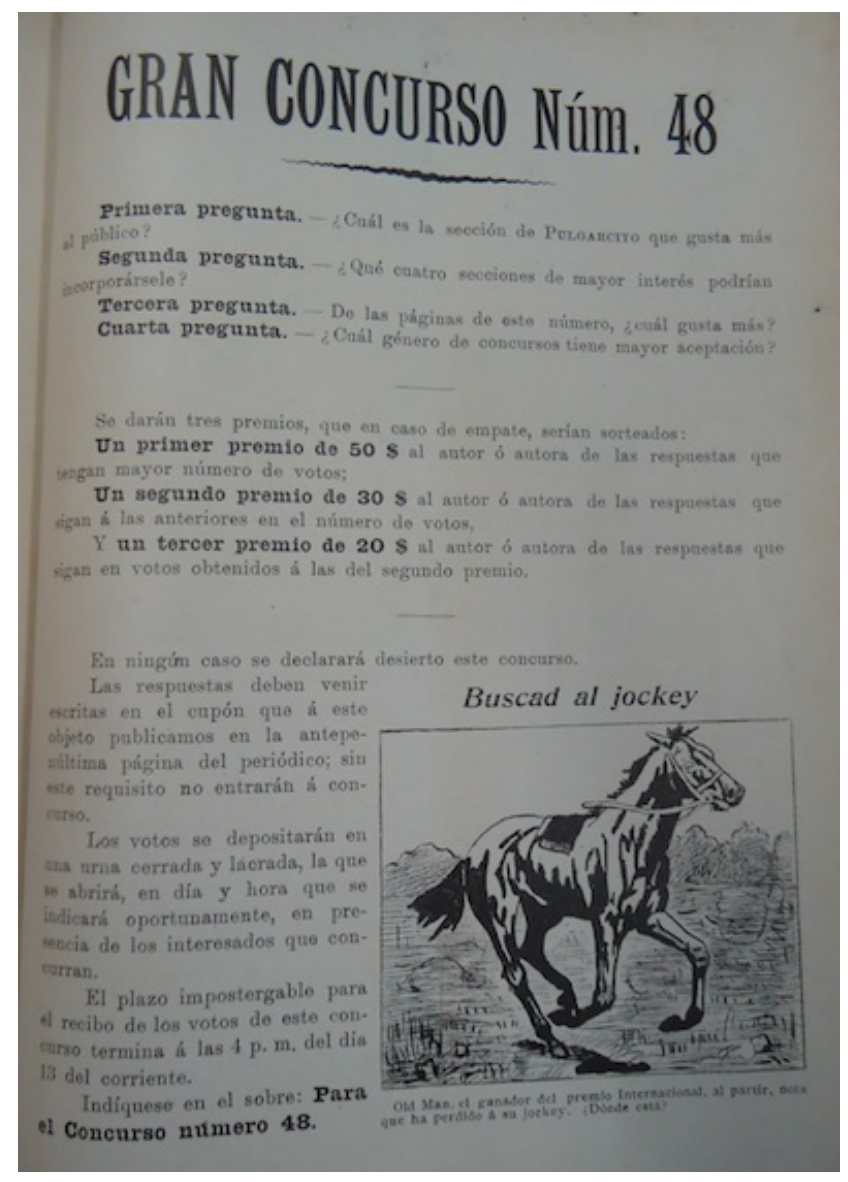

También se desplegaron estrategias genéricas fidelizadoras como inclusión de relatos episódicos, o fotos de competencias y festejos escolares enviadas por los suscriptores. Por su parte, la impresión en los talleres gráficos Rosso hacía posible reducir los costos de la publicación, que hasta diciembre del primer año fue rústica. La apuesta económica se intensificó al finalizar ese año. Luego de continuas consultas y vaivenes, en el editorial del No 16 de diciembre de 1904 se anuncian las "promesas de cambio". Desde el 18 de diciembre de 1904 Pulgarcito pasa a ser un magazine de niños y mujeres y se reduce el precio a la mitad $(\$ 0,10)$ al tiempo que aumenta el tamaño y mejora la calidad del papel (estos cambios retrocederían durante el tercer y último año de la revista). Sin embargo, el precio de venta y las ofertas de suscripción no bastaron para captar lectores. Desde enero de 1905 las tapas presentan contenido político, imitando el estilo de la ya afianzada "Caras y Caretas". ${ }^{21}$

La página destinada a los pictogramas pone en evidencia el radical cambio de público convirtiendo una estrategia de acercamiento al texto escrito y un juego ( $\left.\mathrm{N}^{\circ} 6\right)$ en un recurso paródico ( $\left.\mathrm{N}^{\circ} 27\right)$. 

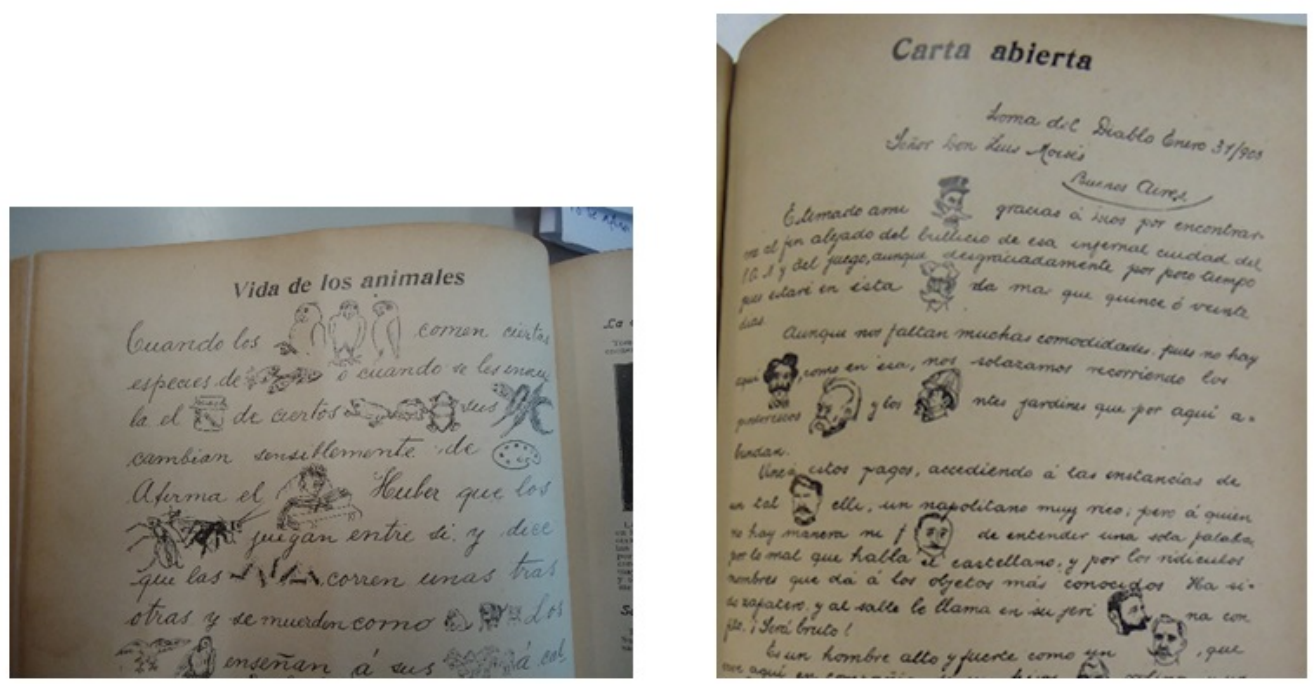

A pocos meses del lanzamiento recrudeció la preocupación por extenderse a nuevos lectores y se apuntó a otro segmento por delimitar: las amas de casa, que no generaban ingresos pero sí definían los consumos familiares. ${ }^{22}$ Desde el $N^{\circ} 16$, junto con el cambio hacia tapas satíricas sobre temas políticos y el paulatino abandono de temas infantiles, comienzan a publicitarse farmacias, jabón, ropa blanca, tinturas para el cabello y pediatras para los "lectores pobres" de Pulgarcito, convocando a su vez los discursos institucionales sobre el rol de la mujer: la higiene del hogar, y el cuidado de la salud y la alimentación de sus integrantes: "Es este el magazin de las madres, el diario de los niños, el amigo del hogar, el compañero de la juventud. Y para que esos tan simpáticos títulos me duren, haré todos los esfuerzos necesarios como así lo pondrá en evidencia la edición del jueves próximo". ("Promesas de cambio", Pulgarcito No 16)

Más tarde, habiendo ya fundado en 1918 la Editorial Atlántida, Vigil señalaba: "la mujer es más de la mitad del público lector de una revista", "son las que directa e indirectamente compran en el 99\% de los casos. Ese convencimiento ha influido para que casi todas mis revistas vayan dedicadas a la mujer". [citado en Ulanovsky, 1997]

Estos acusados virajes daban cuenta de la inestabilidad de un segmento que, si bien se estaba distinguiendo, no era masivo (como sí empezaban a serlo los consumos culturales infantiles anclados en la escuela), ni contaba con medios propios para adquirir un material cuya utilidad no estuviera directamente relacionada con la práctica escolar. De modo que era preciso asignarle un propósito a la lectura ociosa, conservando el delicado equilibrio con la institución proveedora de lectores. De ahí el slogan "útil y divertida" sobre el que insisten los primeros números:

\footnotetext{
¿Sabe cómo lo he defendido hoy en casa donde -quizá por broma- lo atacaban? Pues de una manera muy fácil. Leyéndoles todas las páginas de enseñanza que $\mathrm{Vd}$. trae y pasándome toda una tarde muy quietecita entretenida con los juegos y lindas lecturas que $\mathrm{Vd}$. trae.Cuando me han visto tan juiciosa, han dicho que la revista debía ser muy linda y que no dejarían de comprármela ningún jueves, con lo que me he puesto muy contenta. ( $\mathrm{N}^{\circ} 3$ )

¡Ah! ¡qué lindo, qué lindo es mi querido PULGARCITO! Se ha presentado como una promesa deliciosa para nosotros los niños; como un compañero y como un maestro al mismo tiempo. Nos instruye con cariño, nos aconseja y nos divierte sin cansarnos nunca. ( $\left.\mathrm{N}^{\circ} 6\right)$

Beba, ¿eso te han enseñado en el colegio?

-No, papá: PULGARCITO me lo ha enseñado; léelo y verás lo bueno que es, y todo lo que nos enseña, y cuando conozcas ese personaje no dejarás de comprármelo nunca. ("Colaboración infantil”, No 6)

Mamá dice que tú la ayudas. ¡Cómo nos entretienes! No molestamos a nadie. ( $\left.N^{\circ} 10\right)$

$\mathrm{Tu}$ aparición vendrá á llenar de alegría los momentos que tenemos de ociosidad. ( $\mathrm{N}^{\circ} 2$ )
}

La primera tapa (cfr. supra) contiene un dibujo al estilo de Caras y Caretas y se autoproclama como "la revista que los niños estaban esperando" a través de una viñeta en la que varios grupos de niños dispuestos 
en distintos planos se alegran de la presencia del personaje Pulgarcito, que aparece como figura central. Más adelante ( $\mathrm{N}^{\circ} 3$ ) una fotografía un grupo de niños portando un estandarte con la frase "Papá, queremos Pulgarcito" publicita la revista.

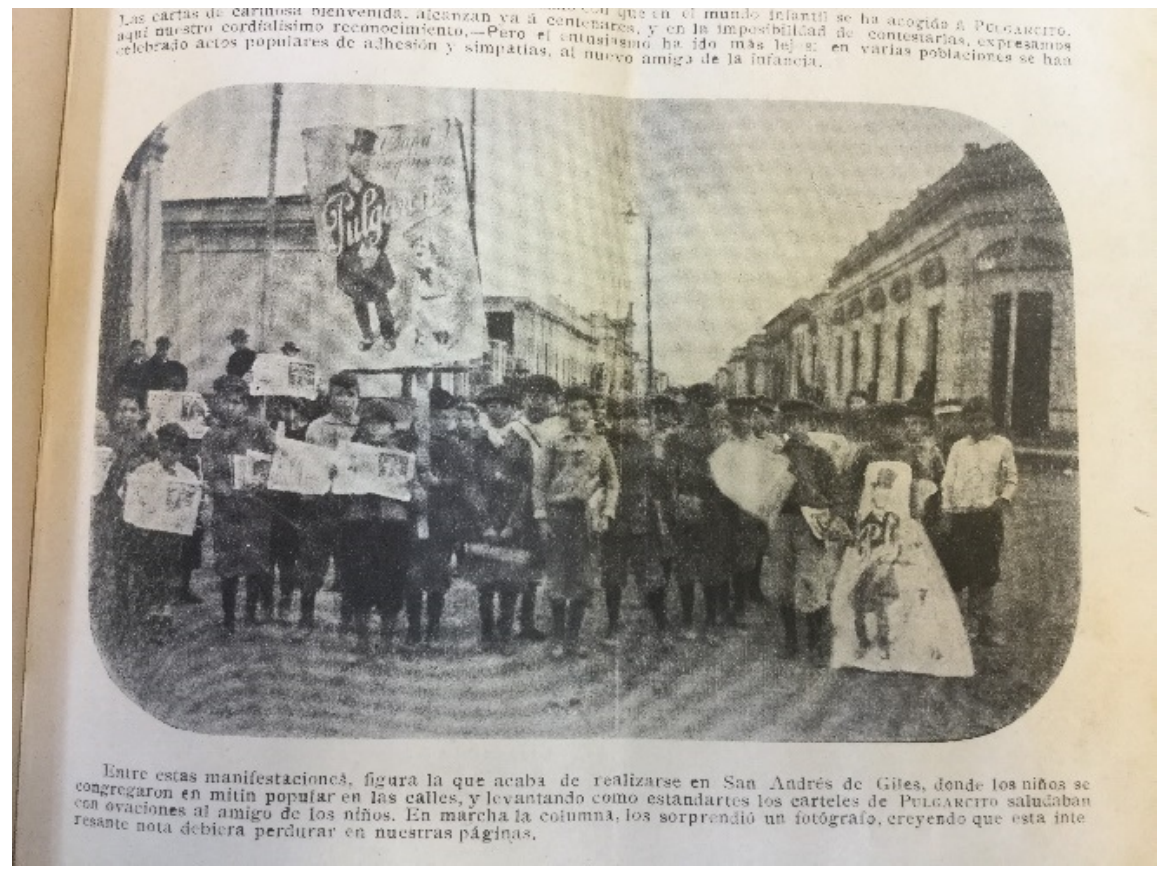

El personaje del texto de Perrault encarna prototípicamente al público de la revista, focalizando la pequeñez como característica central del segmento al que apela, que ocupa (se pretende que ocupe) un espacio diferenciado con necesidades diferenciadas respecto de la oferta editorial para adultos. La revista se postula como compañera de aventuras en la adaptación a las obligaciones específicas de los niños y amortiguando la sujeción a la pauta de comportamiento urbano.

La diferencia radical entre Pulgarcito y las revistas infantiles que la precedieron quedaba expresada en el peculiar vínculo con los contenidos escolares. El reforzamiento de la segmentación por edad y estatuto legal (esto es: la relación administrativa entre la infancia y el Estado) propio de la cultura moderna occidental determinó la inmersión de los niños en la cultura letrada a través de la escuela. Pulgarcito se diferenció como alternativa filiada a la propuesta de la prensa. En esa apuesta, revistas para chicos como Pulgarcito y $P B T^{23}$ (publicada en septiembre de 1904 por Eustaquio Pellicer -fundador de Caras y Caretas-, y cuyo lema era "un semanario infantil para chicos de 6 a 80 años"), ponían de manifiesto la integración del público infantil aunque el contenido (relatos populares, cuentos, chistes, juegos) ${ }^{24}$ alcanzaba, sin afectarse, al mundo adulto despolitizado.

\subsection{Encabalgamiento entre escuela y entretenimiento}

Como decíamos, el relato "Pulgarcito" que da nombre a la revista es la escena englobante y la instala como herramienta de articulación entre el mundo adulto y ciudadano (representado por los padres y la escuela a través de géneros tales como relatos moralizantes, concursos de composición o normativa ortográfica) y el mundo infantil. Los géneros mayoritarios presentes en Pulgarcito son alternativos a los escolares, suponen su lectura en el ámbito privado y se distinguen en tanto lectura de entretenimiento, ${ }^{25}$ disociada de la lectura obligatoria: chistes, adivinanzas, instrucciones para armar juguetes, moldes de ropa para muñecas, reglamentos de juegos y deportes, cartas de lector (un género destinado a estimular el vínculo y la pertenencia a 
la comunidad de la prensa escrita), e imágenes: fotos de juguetes y muñecos, de equipos deportivos, reuniones sociales, etc.

En el plano lingüístico Pulgarcito replica la estrategia del doble destinatario: se dirige a los niños con la lengua de la variedad (representada en el ustedes y sus formas asociadas, así como en el empleo de términos coloquiales, frente al vosotros escolar): "Vengo para ser el mejor compañero de ustedes y acompañarlos todas las horas”; “¿Les gusta mi visita?”; "Buen chasco se han llevado”; “ichúpense esa los automovilistas!”; "Botijín”; "divertirlos", "los quiere mucho a ustedes", "están muy retebonitas". Pero les pide que le respondan con la lengua de la escuela: independientemente de que la escena convocada sea la amistad, el patrón de escritura infantil es escolar: “¡Cuán difícil deciros, lo que más me ha gustado!”, "Oh, mamá, mira el sombrero de papá”, “Quién eres? - pregunta la madre levantándose sobresaltada. -iAbrid, es vuestro hijo!”.

En los concursos (siempre sobre contenidos escolares) y cartas de lector ${ }^{26}$ los niños se sujetan a las formas escolares, salvo contadas excepciones. La revista alienta la atención a la pauta escolar (atención a la ortografía, caligrafía prolija y claridad en la exposición) a la hora de evaluar estas participaciones; de hecho, la firma del niño debe estar acompañada por nombre de la escuela y del maestro: ${ }^{27}$

[...] Antes de pasar á dar cuenta del resultado, advierto que el jurado de premios es muy severo y se fija mucho en la mala caligrafía y las faltas gramaticales de las composiciones. No pocas de éstas vienen con tan visible desaliño que esta sola circunstancia es bastante para que no sean tomadas en cuenta. ( $\mathrm{N}^{\circ} 5$ )

Toda composición que tenga tres faltas graves de ortografía, que esté escrita con muy mala letra, ó tenga borrones, la echo al canasto."[Concurso de escritura ํo30] ( $\left.\mathrm{N}^{\circ} 11\right)$.

Se valida allí la escritura como vía de participación en la sociedad: ser publicado es un reconocimiento, signo del éxito individual, del docente y de la institución. En los concursos Pulgarcito se apropia de distintos roles garantes: es la puesta en práctica de la escritura, instancia de evaluación y premio, objeto deseado. ${ }^{28}$ Mientras que en otros géneros queda subordinado, igualado a los niños frente a la escuela:

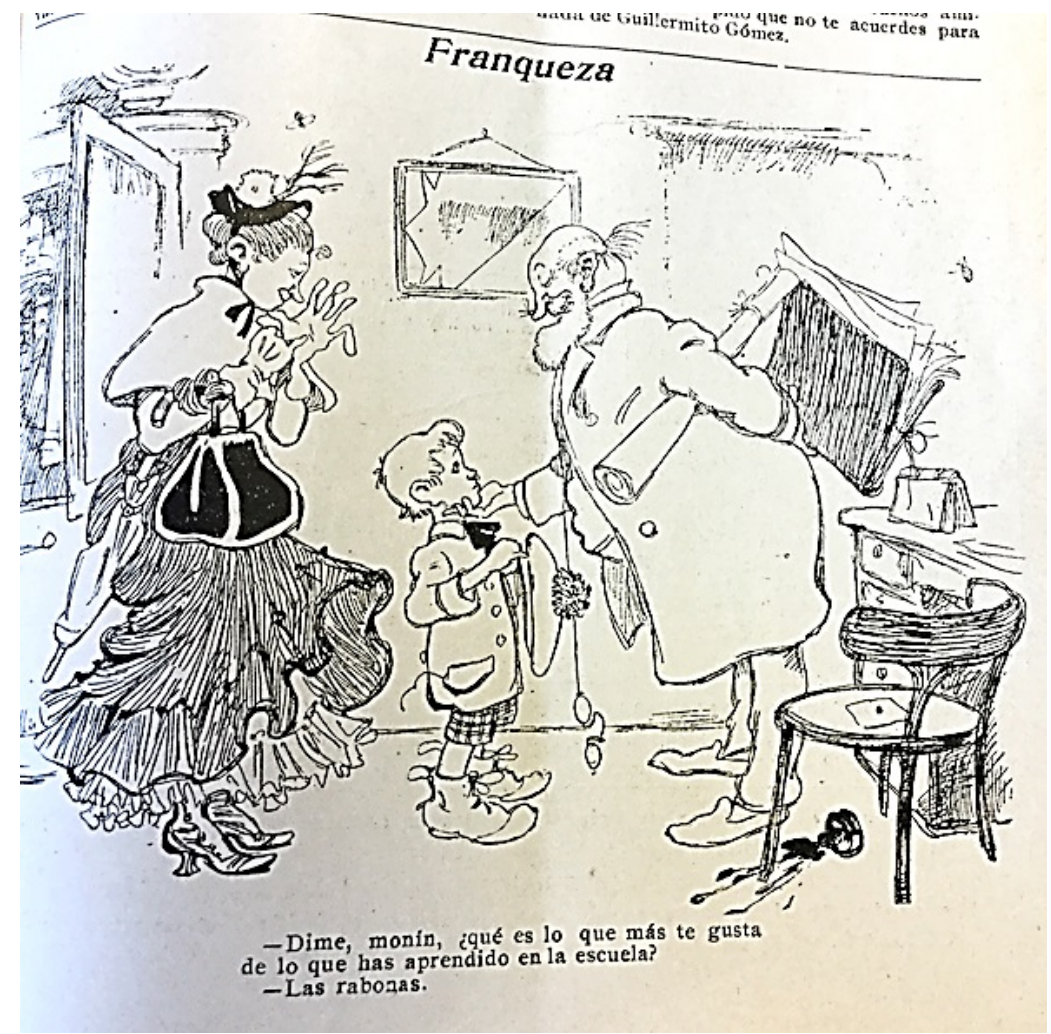




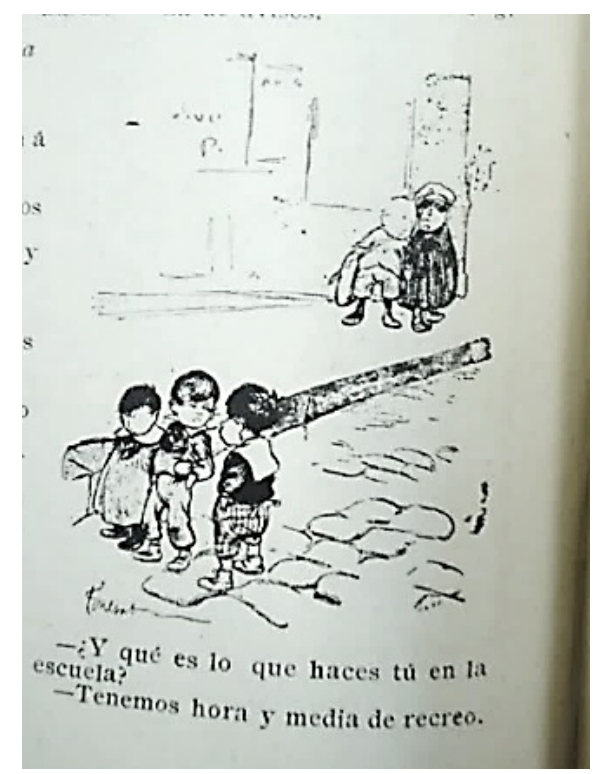

Pulgarcito se dirige también a los padres como destinatario indirecto pero necesario. Hay un despliegue persuasivo orientado a justificar la compra evocando la utilidad de la revista como complemento escolar. Ese sujeto lector ampliado potencia ciertas zonas en la construcción del ethos en los distintos géneros. En los editoriales, por ejemplo, coincidían Pulgarcito personaje, compañero de aventuras y práctica de lectura extraescolar con Pulgarcito revista, complemento de la escuela y ordenadora del tiempo libre. Las variaciones en el léxico y en las formas pronominales (que veremos inmediatamente) dan cuenta de este doble propósito. Además, la multiplicidad de géneros breves le permitía moverse entre el polo de la formalidad escolar y la coloquialidad escrita (tuteante y semiformal).

Sin embargo, no acordaba punto a punto con los contenidos escolares. No acudía a la partición en las asignaturas prescriptas en la legislación educativa (en este caso el artículo 6 de la Ley 1.420, del año 1884), ni buscaba complementar la tarea del maestro, como lo hicieran las revistas infantiles anteriores. Pulgarcito buscó emular el estilo informal, las temáticas de entretenimiento y la gráfica de las revistas contemporáneas para adultos. Las variaciones en los pronombres y el lexicón respondían al firme propósito de establecer un vínculo directo con el segmento infantil desde un lenguaje de la prensa. Incluso al finalizar el primer año de la revista, cuando la publicación fracasaba, la solución buscada no fue acercarse a la escuela sino, progresivamente: afianzar su lugar entre las revistas de lectura extraescolar, imitar publicaciones periódicas de impacto y salir a ganar nuevos públicos. Pulgarcito es la primera revista infantil que deliberadamente se coloca e intenta permanecer entre las propuestas de la prensa escrita, a prudente distancia de los textos escolares. El kiosco para armar que sirvió de contratapa del No 1 (reproducido aquí más arriba) es elocuente en ese sentido.

\subsection{Variación entre la lengua escolar y la lengua de la prensa}

Los primeros números alternan formas pronominales del vosotros, respetando las fórmulas de tratamiento alentadas por la escuela, con el ustedes. En los editoriales, firmados por el personaje “Pulgarcito", en los que se advierte la alternancia incluso en un mismo párrafo, las variantes no parecen responder a contextos sintácticos o semánticos específicos y esa condición se repite en todos los números:

Como tendrán ustedes que escribirme á menudo, ha llegado el momento, mis buenos amigos, de que yo sepa cómo saben redactar. Al mismo tiempo he traído tantos objetos útiles para regalaros que aprovecharé la ocasión de conocer vuestras aptitudes y los iré distribuyendo según los méritos.

He aquí en qué consiste la primera prueba á que los someto, previniéndoles que cada semana hay una diferente. 
Necesito saber qué impresión os he producido, si soy acreedor á vuestra amistad, si os he agradado por mi forma, por mis figuras, por mis cuentos, si os he entretenido. ( $\mathrm{N}^{\circ} 2$ )

Las variantes funcionan en la misma lógica que otros aspectos de la revista: se encabalga entre las fórmulas escolares, necesarias para su permanencia y aceptación entre el público de padres con la potestad de comprar la revista;

Tomad un vaso y llenadlo de agua [...] podréis colocar en este vaso... ( $\mathrm{N}^{\circ} 6$ )

Trazad sobre la muselina los dos cuadrados ABCD; plegad la tela en cada ángulo sobre la línea BD [...] y probaréis la forma en vuestra muñeca... ( $\left.\mathrm{N}^{\circ} 11\right)$

las formas de la oralidad deseada, más relajadas (que no incluían el vosotros, pero sí el tú), que aparecían en las cartas, relatos, obras de teatro y toda forma de diálogo infantil;

Tú siempre eres tan amable conmigo proporcionándome agradables momentos con tus bonitas é instructivas lecturas. ( $\left.\mathrm{N}^{\circ} 5\right)$

Te agradezco íntimamente el regalo de Pulgarcito que me has hecho [...] Figúrate que aquí... (№ 6)

Juanita: -Ve á buscar a la niña, y si ves á Gaspar dile que venga también. ( No 15)

Te envío esta nenita para ver si te parece bien para tí. Creo que tú mereces algo mejor... (No 16)

y las formas regionales, cuya presencia se registra en voces marginales como negros, personajes rurales o chistes. Las zonas laterales dejaban aparecer la variedad regional oral, instalando la interpelación informal como lenguaje de la prensa en su función de entretenimiento (la función informativa o la opinión empleaba la norma considerada correcta). Este fenómeno se advertía también en publicaciones contemporáneas para adultos. En ese espacio en el que, según sostiene Francine Masiello, "se ponen a prueba los usos del lenguaje cotidiano [...] se ofrece un coqueteo contra la institucionalización de la lengua" (Masiello, 1994: 305).

Medida acertada

¿¿Cuántus acentus hay, hijo mío?

-Tres, papá.

-¿Cuáles son?

-El acento grave, el agudo y el circunflejo.

-¿Y no hay ningunu más, hombre?

-No, papá

-Busca bien, que aun hay otro que has olvidado.

-No lo encuentro, papá.

-¿Y el acentu gallegu, te parece que es un sacu de paja? ( $\mathrm{N}^{\circ}$ no)

DIÁLOGO INFANTIL

Lucía. -¿®Me querís Carolino?

Carolino. - ¿Tenís calamelo?

Lucía.-No, mañana tendré.

Carolino. -Bueno, hoy no te voy quelé, mañana sí.

J. Constanto (Tucumán) ( $\left.N^{\circ} 16\right)$ 

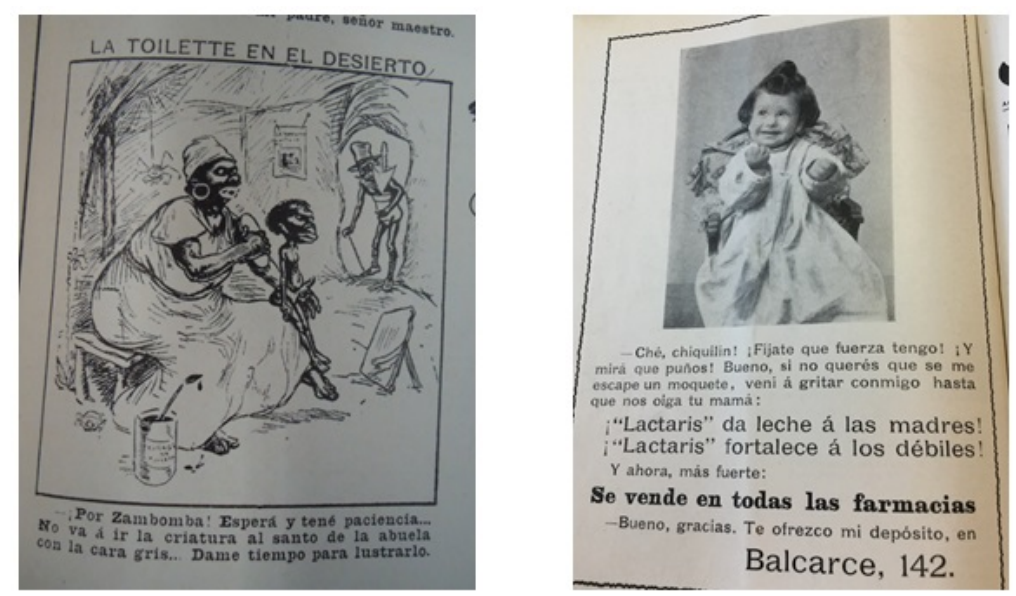

Estas últimas están liberadas del corsé normativo en tanto formas laterales, géneros destinados claramente al "entretenimiento", que Pulgarcito parece distinguir respecto del "ocio productivo" (Dumazedier, 1968; Cuenca Cabeza, 2006).

\section{CONCLUSIONES PRELIMINARES}

Pulgarcito inicia el derrotero de la distribución social de la lectura: la lectura escolar conforma el universo de lo que debe saberse y la prensa el modo en que se debe ser parte de la sociedad moderna. Los consumos (la lectura entre ellos) operaron así como una forma de socialización, como herramienta para integrarse a los circuitos comerciales y participar de un colectivo con las mismas aspiraciones. En ese sentido la prensa infantil iniciada con Pulgarcito funcionó como guía para la vida urbana complementando a la escuela. Intentó adiestrar para un ocio "productivo" y conducente a reprimir la corporalidad reorientándola al deporte, a la quietud, la lectura en voz baja, la diversión solitaria, ordenando la circulación del niño por el espacio social para facilitar la ciudadanización de ese nuevo agente diferenciado. De este modo Pulgarcito empieza a torcer con el Estado por retener el control sobre ciertas zonas de la infancia. El Estado, por su parte, se apropia de las propuestas de la prensa y las difunde desde sus instrumentos de comunicación, pero hace explícita cierta tensión: ${ }^{29}$

\footnotetext{
Una revista para niños debe tratar de ejercitar las facultades en todo sentido, incitándolos a la acción, al esfuerzo, a la confianza en si mismo y al deseo de ser alguien. [...] Necesita ver, conocer, comprender. Su imaginación ha variado y se mueve en un mundo de imágenes y deseos que los niños del pasado no conocían.Las tontas historias de los moralistas edificantes, ya no se usan. Una obra impregnada de sensiblerías y de prejuicios, ya no educa a nuestros niños.Una revista infantil debe ser dirigida por médicos, psicólogos, dentistas, escritores, profesores y maestros que conozcan ampliamente la naturaleza del niño, a fin de que contribuyan con eficacia a su paulatino desarrollo en todo sentido. (Monitor de la Educación Común, año 42. 1924: 17-18. Eduardo Acevedo)
}

La revista se instaló en el umbral que divide al juego del mundo escolar. Reprodujo y educó un vínculo que se fortalecería a lo largo del siglo XX entre el trabajo y la diversión: "Para generar mayor productividad, el capitalismo de la emoción se apropia del juego, que propiamente debería ser lo otro del trabajo. Ludifica el mundo de la vida y del trabajo. [...] Mientras uno juega, se somete al entramado de la dominación."ByungChun Han (2015: 65)

En el plano lingüístico, esa doble valencia se manifestó en la coexistencia de variables vinculadas con el patrón escolar, las formas más o menos estandarizadas de la variedad regional, y las formas (pronominales y léxicas) orales -siempre asociadas a géneros menores-. En ese aspecto es donde Pulgarcito hace patente su falta de consolidación y un problema que la prensa debía entonces resolver: la necesidad de definir cuáles serían las formas lingüísticas del ocio infantil, es decir, las formas de comunicación extraescolar de esos niños 
que eran una comunidad diferenciada (que se extendía a todo el país y que alcanzaba en las cartas a los países limítrofes y, en las fotografías, a los de otras latitudes). Con Pulgarcito nacían en la Argentina la comunidad imaginada de los niños y la lengua de la prensa infantil.

\section{REFERENCIAS}

Adorno, T. y Horkheimer, M. (1988). La industria cultural. Iluminismo como mistificación de masas. En Dialéctica del iluminismo. Buenos Aires: Sudamericana.

Alonso, P. (comp.) (2003). Construcciones impresas. Panfletos, diarios y revistas en la formación de los estados nacionales en América Latina (1820-1920). Buenos Aires: FCE.

Alvarado, M. y Massat, E. (1989). El tesoro de la juventud, Filología 1-2 (XXIV), 41-59.

Barbier, F. y Bertho-Lavenir, C. (1999). Historia de los medios. De Diderot a internet. Buenos Aires: Colihue.

Blanchard, J. (ed.) (1994). Labour and Leisure in Historical Perspective: Thirteenth to Twentieth Centuries. Stuttgart: Franz Steiner.

Bontempo, M. C. (2012). Editorial Atlántida. Un continente de publicaciones (1918-1936) (Tesis doctoral), Universidad San Andrés, Buenos Aires, Argentina.

Briggs, A. y Burke, P. (2002). De Guttenberg a internet. Una historia social de los medios de comunicación. Madrid: Taurus.

Butera, A. (2012). Pioneros del tabaco. Los fabricantes de cigarrillos en la Argentina 1880-1920. Bariloche.

Cowen, P. (2004). Infancia, abandono y padres en el s. XIX porteño, Anuario del Instituto de Historia Argentina (4), Universidad Nacional de La Plata, 75-99.

Cuenca Cabeza, M. (ed.) (2006). Aproximación multidisciplinar a los estudios de ocio. Bilbao: Universidad de Deusto.

Demarco, M. (2009). Constitución del Espacio literario en la escuela de la Argentina Moderna: El caso de la revista Figuritas. En R. Spregelburd y C. Linares (orgs.) La lectura en los manuales escolares. Textos e imágenes. Buenos Aires: UNLU/UNNE.

Dumazedier, J. (1968). Hacia una sociedad del ocio. Barcelona: Estrella.

Elias, N. y Dunning, E. (1992). Deporte y ocio en el proceso de la civilización. Madrid: Fondo de Cultura Económica.

Fritzsche, P. (2008) [1996]. Berlín 1900. Prensa, lectores y vida moderna. Buenos Aires: Siglo XXI.

Galván de Terrazas, L. (2005). Del ocio a la instrucción en la niñez ilustrada. Un periódico infantil del siglo XIX, Estudios del hombre, 20, 201-233.

García, E. (1965). Desarrollo de la industria editorial argentina. Buenos Aires: Fundación Interamericana de Bibliotecología Franklin.

Gombrich, E. (2003). Los usos de las imágenes. Barcelona: Debate.

Gratton, C. y Taylor P. (2000). The Economics of Sports and Recreation: an Economic Analysis. Londres: FN Spon.

Gutiérrez, J. M. (2014). Las aventuras de un matrimonio sin bautizar. Buenos Aires: Biblioteca Nacional.

Habermas, J. (1981). Historia y critica de la opinión pública. Barcelona: Gilli.

Han, B-Ch. (2015). Psicopolítica. Neoliberalismo y nuevas técnicas de poder. Barcelona: Herder.

Lionetti, L. y Míguez D. (comps.) (2010). Las infancias en la historia argentina. Intersecciones entre prácticas, discursos e instituciones (1890-1960). Buenos Aires: Prohistoria.

Lionetti, L. (2007). La misión política de la escuela pública. Formar a los ciudadanos de la república (1870-1916). Buenos Aires: Miño y Dávila.

Lyons, M. (1998). Los nuevos lectores del siglo XIX: mujeres, niños, obreros. En G. Cavallo y R. Chartier (eds.). Historia de la lectura en el mundo occidental. Madrid: Taurus.

Malosetti Costa, L. y Gené M. (comps.) (2009). Impresiones porteñas. Imagen y palabra en la historia cultural de Buenos Aires. Buenos Aires: Edhasa. 
Martínez Valle, M. (1997). Medios gráficos y técnicas periodísticas. Buenos Aires: Editorial Macchi.

Mases, E. (2013). El trabajo infantil en la Argentina 1900-1945. Miradas contradictorias y políticas controversiales, Estudios Sociales (UNL), (45): 131-166. Recuperado de: https://bibliotecavirtual.unl.edu.ar/ojs/index.php/Es tudiosSociales/article/viewFile/4455/6772

Masiello, F. (1994). 'Gentelmen', damas y travestis: ciudadanía e identidad cultural en la Argentina del fin de siglo. En L. Área y M. Moraña (comps.). La imaginación histórica en el siglo XIX. Rosario: UNR Editora, 297-309.

Montaigne, M. de (2005). Ocio y negocio en la Edad Moderna. En R. Chartier (ed.). El presente del pasado. Escritura de la historia, historia de lo escrito. México: Universidad Iberoamericana, 133-164.

Morduchowicz, R. et al. (2010). Los medios para chicos: una historia centenaria. Ministerio de Educación, Presidencia de la Nación.

Pastormerlo, S. (2014). El surgimiento de un mercado editorial. En J. L. de Diego (ed.). Editores y políticas editoriales en Argentina (1880-2010). Buenos Aires: FCE, pp. 1-29.

Poser, S. (2011). Leisure Time and Tecnology, European History Online. Recuperado de: http://ieg-ego.eu/

Rodríguez López, C. (2010). La niñez abandonada y delincuente al iniciar el siglo XX. Los menores vendedores de periódicos, Primera Jornada Abierta Interdisciplinaria. Instituto de Investigaciones Jurídicas y Sociales, Facultad de Derecho (UBA).

Romano, E. (2004). Revolución en la lectura. El discurso periodístico-literario de las primeras revistas ilustradas rioplatenses. Buenos Aires: Catálogos.

Sosenski, S. (2012). El niño consumidor: una construcción publicitaria de mediados de siglo XX. En A. Acevedo y P. López Caballero. Ciudadanos inesperados. Espacios de formación de la ciudadanía ayer y hoy. México: El Colegio de México.

Szir, S. (2009a). Entre el arte y la cultura masiva. Las ilustraciones de la ficción literaria en Caras y Caretas. En L. Malosetti Costa et al. Imagen y palabra en la historia cultural de Buenos Aires. Buenos Aires: Edhasa, 109-140.

Szir, S. (2009b). De la cultura impresa a la cultura de lo visible. Las publicaciones periódicas ilustradas en Buenos Aires en el siglo XIX. En M. Garabedián et al. Prensa argentina siglo XIX. Buenos Aires: Teseo/Biblioteca Nacional.

Ulanovsky, C. (1997). Paren las rotativas. Historia de los grandes diarios, revistas y periodistas argentinos. Buenos Aires: Espasa.

Zapiola, Ma. C. (2009). ‘Es realmente una colonia? ¿Es una escuela? ¿Qué es?’ Debates parlamentarios sobre la creación de instituciones para menores en la Argentina, 1875-1890, Revista Horizontes, Universidade São Francisco, 27 (2).

Zapiola, Ma. C. (2010). Espacio urbano, delito y 'minoridad': aproximaciones positivistas en el Buenos Aires de comienzos del siglo XX, Revista Educación y Pedagogía, Universidad de Antioquia 22, 57.

Zapiola, Ma. C. (2013). En los albores de lo institucional. La gestación de instituciones de reforma para menores en Argentina. En\#V. Llobet et al. (comps.).Pensar la infancia desde América Latina: un estado de la cuestión. Buenos Aires: CLACSO, 159-183.

\section{Notas}

1 El artículo es parte de un trabajo de recolección y análisis de las revistas infantiles argentinas hasta comienzos del siglo XX radicado en el CONICET. Esta investigación es, a su vez, parte de un proyecto mayor, dirigido por Juan Ennis y financiado por la Agencia Nacional de Promoción Científica y Tecnológica. Una versión preliminar fue presentada en el III Congreso Latinoamericano de Glotopolítica en septiembre de 2017, Leibniz Universität Hannover.

2 Paula Bontempo (2012: 141) postula -aunque informa que no pudo comprobarlo documentalmente- que Vigil fue parte del staff de la editorial Haynes y dirigió la revista "El (consejero del) hogar", pensada originalmente para las mujeres de clase media con aspiraciones y clase alta con necesidad de exposición. Esto explicaría el primer intento que hace Vigil de viraje hacia un público extendido de Pulgarcito. La revista, pensada para la lectura infantil extraescolar, intenta ganar otros lectores del mismo hogar apuntando al agente familiar con poder de decisión sobre el consumo de bienes (en este caso, suntuarios). Por su parte, José María Gutiérrez (2014) reconoce esta misma filiación en el propósito de la segunda 
revista fundada por Vigil, "Billiken" (1919): “clonando la estrategia de "El Hogar" al adaptar eficazmente su función de modelo e intérprete para la familia burguesa modélica -e interpretadora- para los niños.” (Gutiérrez, 2014: 10.)

3 El periodista español Eustaquio Pellicer, llegado desde su Burgos natal a Montevideo en 1886, había fundado en esa misma ciudad la primera versión de "Caras y Caretas" en 1890, iniciando el camino de "coincidencias" entre ambas propuestas.

4 Cecilia Bontempo (2012) se extiende sobre las decisiones empresariales que toma Vigil (selección de personal, estrategias de relación con los subordinados, diseño de productos, etc.) con el claro propósito de colocar a Atlántida como empresa ligada a la moral -intención que la autora vincula con la afiliación de Vigil al georgismo- y fortalecer la identificación entre empresa y familia (los puestos de jerarquía eran ocupados -lo están todavía en la actualidad- por familiares o gente del entorno del fundador); esa estrategia, que consideramos publicitaria, buscaba identificar pauta moral, empresa y apellido de su fundador. Estas operaciones se reflejan en la tendencia de los relatos incluidos en las revistas y los libros morales que Constancio Vigil publicaría años más tarde como autor. Por su parte, la profusión de relatos morales en Pulgarcito llevaba la firma de la dirección y descuidaba gravemente los aspectos estilísticos y estéticos. Esos relatos morales instalaban la idea del propósito de lectura y la existencia de un mensaje a develar.

5 La tapa blanda era de papel grueso y a color, tipo glacé, mientras que el resto de la revista era de papel rústico impreso en negro. Las características del papel, así como el tamaño $(20 \times 30 \mathrm{~cm}$.) la hacían manejable y, sobre todo, económica.

6 Como explica Sandra Szir (2009a: 113), el grabado en acero o litografía era la técnica de reproducción de imágenes empleada en la Argentina hasta fines del siglo XIX, eso suponía ilustraciones separadas respecto del texto. Fue a comienzos del XX que se expandió el grabado en madera o el fotograbado de medio tono (empleado en Estados Unidos desde 1880 y en Europa desde 1891), lo que permitió reproducir todo tipo de imágenes en forma industrial y, por lo tanto, integrar las imágenes al texto produciendo nuevos sentidos y, naturalmente, nuevas formas de leer. Según esta investigadora, fue "Caras y Caretas" la publicación impulsora de la prensa ilustrada, propiciada por estos adelantos como condiciones de posibilidad.

7 Para fines de siglo XIX existían alrededor de $16.500 \mathrm{~km}$. de vías. La red, organizada en torno al puerto de Buenos Aires, tenía centros de interconexión importantes en Rosario y Bahía Blanca. Los puntos máximos desde Buenos Aires eran La Sabana, Chaco, $(700 \mathrm{~km}$.), Jujuy al noroeste $(1.600 \mathrm{~km}$.), Mendoza y San Juan al oeste (más de $1000 \mathrm{~km}$.) y Neuquén al sur $(1200 \mathrm{~km}$.). (fuente, Wikipedia)

8 Pastormerlo hipotetiza a partir de datos de Juan María Gutiérrez que "las publicaciones costeadas por el Estado eran poco más de un tercio del total en 1863. Si se concede alguna credibilidad a este dato, habrá que concluir que la participación estatal creció en la década de 1880, a pesar de la expansión del aparato estatal”. (Pastormerlo, 2014: 7)

9 Briggs y Burke se extienden sobre el estrecho vínculo entre el "nuevo periodismo" que surgiría durante el XIX con la modernización de la prensa y el acceso de las capas bajas a la alfabetización, y las noticias breves de entretenimiento. Sostienen que no debe sobreinterpretarse la importancia de la alfabetización masiva en la formación del público lector, sino más bien lo contrario "Por sí misma, la extensión de la educación elemental [...] sólo nos entregará mayor número de gente capaz de leer las secciones policiacas de peor calidad en los periódicos semanales y con escaso interés en leer otra cosa" (citado por Briggs y Burke, 2002: 226). Las noticias breves y de entretenimiento, sostienen, ocupaba a fines del XIX un lugar de importancia en las publicaciones para la clase obrera. La publicidad, por su parte, la convirtió en un negocio rentable, lo que otorgó a los gustos de los lectores una importancia inusitada y la convirtió en "una rama del comercio".

10 Los concursos eran una práctica usual en las publicaciones de la época. Funcionaban como primitivos focusgroup que permitían conocer intereses y formas de consumo. Al mismo tiempo, financiaban parte de los costos de publicación y fidelizaban al público.

11 El censo de 1895 registra 145 periódicos solo en el ámbito de la Capital Federal (cfr. capítulo VI, cuadro I d. p. 249 y Anexo: 49). Las revistas infantiles no computan como una categoría independiente, quedan bajo "Educación, instrucción pública, pedagogía" en la que se registran solo 10 a ese año. (Tomo III, p. LXVIII)

12 Es interesante la tapa del primer número de Billiken (publicación que retomaría en 1919 el proyecto que en Pulgarcito fracasó), que salda definitivamente la diferencia entre "niño" y "menor" colocando en primer plano a un niño desalineado, sucio y callejero bajo el mote "el campeón de la temporada” (amparándose con la ambigüedad de la referencia al deporte), reconociéndolo como su destinatario. Esa tapa, es preciso mencionar, es una copia directa del número de noviembre de 1914 de la publicación inglesa The Saturday Evening Post.

13 Lecturas pensadas en clave de las "Penny magazine", surtido semanal de lecturas de entretenimiento. El concepto de lectura de entretenimiento y su relación con el abaratamiento del soporte, se encuentra desarrollado para el caso inglés en Lyons (1998).

14 Byung Chul Han habla de los AIE como "espacios disciplinarios de reclusión", "el sujeto disciplinario cambia de un entorno de reclusión a otro” (Han, 2015: 19). Esta idea es productiva para entender la función de la lectura ociosa, del consumo de revistas, como herramienta de control del tiempo fuera de la escuela, en especial para los niños que ahora estaban previstos como público no trabajador y no necesariamente al ciudado/control de las familias. Está en la línea del clásico trabajo sobre la industria cultural de Adorno y Horkheimer (1988), quienes advierten la íntima relación entre la 
diversión (entendida como lo contrario del aburrimiento) y la prolongación del trabajo, en tanto el amusement permite al trabajador volver a estar en condiciones de afrontar su rol.

15 Weaver Pangburn, entonces presidente de la Asociación Nacional de Recreación Norteamericana, mencionado por Susan Currell (2005) en su libro The march of Spare Time, como promotor del vínculo entre el ocio productivo y la elevación eugenésica.

16 Vigil, hábil identificador de nichos de mercado de la prensa, ingenió para la revista la "Copa Pulgarcito".

17 Deportes masculinos traídos a la Argentina por los inmigrantes ingleses que venían construir el ferrocarril y se radicaron en el corredor norte de la Ciudad de Buenos Aires, donde aún hoy subsisten algunas casonas de los administrativos ingleses, iglesias protestantes y clubes de rugby.

18 Cuenca Cabeza (2006) afirma que la bibliografía sobre la pedagogía "del tiempo libre” encuentra referentes recién hacia comienzos del siglo XX y aparece estrechamente vinculada con instituciones del tipo BoyScouts o clubes deportivos o asociaciones de beneficencia.

19 Elias y Dunnig (1992) en la introducción a Deporte y ocio en el proceso de la civilización hipotetizanla posibilidad de rastrear los orígenes de algunos "deportes de combate" modernos en una serie de juegos tradicionales populares cuya violencia trasluce su arraigo a una sociedad más patriarcal que la nuestra.

20 Vigil replicaría años más tarde la formación y reproducción de estereotiposen la segmentación por género de las revistas. Creó El gráfico (1919), que educó la sublimación de la energía masculina en el consumo del deporte espectacularizado, y la femenina de variedades Para ti (1922), que corroboraba el destino doméstico de la mujer. Intentó también la subsegmentación de la infancia con la fundación de Marilú (1933) (homónima de una famosa muñeca surgida hacia 1932) para diferenciarla de la precoz revista Billiken (1919) (que hasta entonces era para ambos sexos y pasaría a ser solo para varones). Tal fue la popularidad de la muñeca (y el compulsivo interés por fomentar el consumo infantil) que en la entonces reputada calle porteña Florida se instaló un local de venta de los mismos modelos de ropa para las muñecas y sus dueñas (llamadas "mamitas" por la revista). "Casa Marilú [Bragance], el palacio donde se esconden las hadas, donde convierten a las niñas en deliciosas muñecas. Nuestros modelos son copias fieles de los que continuamente recibimos de París y Londres, no admiten competencia." Esa revista no tuvo éxito y solo perduró Billiken como revista para niños de ambos sexos.

21 La inestabilidad y la falta de rumbo claro en temas y géneros continuaron hasta acabar con la revista, que pasó de ser una "Revista para niños", "Magazine de las madres" (No 17) a un "Semanario humorístico ilustrado" (No 19), luego "Semanario festivo y de actividades" (a partir del No 73) y, finalmente, "Semanario de Letras y Actualidades" (desde el No 78).

22 En las publicidades se plasma ese paulatino cambio. En los primeros números, hasta mediados de diciembre de 1904, las publicidades son: Librería del Colegio, Editorial Cabaut, trajes para niños, pianos, cacao, blanco y lencería, digestivos, juguetes, caramelos ingleses Diamond, Bizcochos Canale, leches, harina lacteada.

23 Al igual que PBT, las tapas de Pulgarcito hacían alusión a las contingencias de la vida política. La diferencia definitiva se plasmaba en las publicidades, destinadas en el primer Pulgarcito exclusivamente al público infantil.

24 Maite Alvarado (1989) ordena este punto indicando que "infantil" es el destino de la lectura y no el origen, pero que las diversas necesidades que enmarcan la atención sobre ese público terminan sobredeterminando la aparición de marcas que los textos originariamente no tienen. Ella ve en estos gestos la decisión política de intervenir en la imaginación de los niños a través del empleo pedagógico del cuento y de los relatos populares como forma de control social de las clases populares y de la burguesía en ascenso.

25 Sandra Szir (2009a) alude a la vigorosa discusión mantenida durante el período entre posturas que señalaban como disparates la aparición de elementos fantásticos y maravillosos e insistían por el camino de la moralización frente a propuestas (a las que, en parte, suscribían las historietas de Pulgarcito) que entendían los géneros de la lectura ociosa como subversión del orden "natural".

26 No es posible afirmar con certeza que la correspondencia recibida los primeros números fuera real, las intervenciones de los niños parecen más bien ser una estrategia publicitaria de la revista.

27 Aunque la revista establecía así puntos de contacto con las prácticas de escritura escolar, no sucedía lo mismo con la lectura: los fragmentos destinados a la lectura recreativa y/o edificante no participaban del canon, sino que estaban escritos por el mismo Vigil, su director, quien se declaraba único responsable de los textos aunque fueran colaboraciones externas.

28 La capacidad de sintetizar distintas funciones genéricas, emisores y garantes de la información se advierte actualmente en los libros de texto escolares, gestionados desde conglomerados transnacionales en poder de los medios masivos de comunicación.

29 Esa primera búsqueda de Pulgarcito, esa primera identificación/construcción del público infantil y de los temas escolares como potenciales mercancías, continuaría en una larga tradición de relaciones conflictivas entre el Estado y las empresas editoriales con intereses en la educación. 